\title{
Effect of dimethyl fumarate on lymphocytes in RRMS
}

\section{Implications for clinical practice}

Devangi Mehta, PhD, * Catherine Miller, PharmD,* Douglas L. Arnold, MD, Eris Bame, BS, Amit Bar-Or, MD, Ralf Gold, MD, Jerome Hanna, MB BCh, Ludwig Kappos, MD, Shifang Liu, PhD, André Matta, MD, PhD, J. Theodore Phillips, MD, PhD, Derrick Robertson, MD, Christian A. von Hehn, MD, PhD, Jordana Campbell, BSc, Karen Spach, PhD, Lili Yang, PhD, and Robert J. Fox, MD

Neurology ${ }^{\circledR}$ 2019;92:e1724-e1738. doi:10.1212/WNL.0000000000007262

\begin{abstract}
Objective

To assess functional changes in lymphocyte repertoire and subsequent clinical implications during delayed-release dimethyl fumarate (DMF) treatment in patients with multiple sclerosis.
\end{abstract}

\section{Methods}

Using peripheral blood from several clinical trials of DMF, immune cell subsets were quantified using flow cytometry. For some patients, lymphocyte counts were assessed after DMF discontinuation. Incidence of adverse events, including serious and opportunistic infections, was assessed.

\section{Results}

In DMF-treated patients, absolute lymphocyte counts (ALCs) demonstrated a pattern of decline followed by stabilization, which also was reflected in the global reduction in numbers of circulating functional lymphocyte subsets. The relative frequencies of circulating memory $\mathrm{T}$ - and B-cell populations declined and naive cells increased. No increased incidence of serious infection or malignancy was observed for patients treated with DMF, even when stratified by ALC or T-cell subset frequencies. For patients who discontinued DMF due to lymphopenia, ALCs increased after DMF discontinuation; recovery time varied by ALC level at discontinuation. T-cell subsets closely correlated with ALCs in both longitudinal and cross-sectional analyses.

\section{Conclusions}

DMF shifted the immunophenotype of circulating lymphocyte subsets. ALCs were closely correlated with $\mathrm{CD}^{+}$and $\mathrm{CD}^{+}{ }^{+}$T-cell counts, indicating that lymphocyte subset monitoring is not required for safety vigilance. No increased risk of serious infection was observed in patients with low T-cell subset counts. Monitoring ALC remains the most effective way of identifying patients at risk of subsequently developing prolonged moderate to severe lymphopenia, a risk factor for progressive multifocal leukoencephalopathy in DMF-treated patients.

\section{Trial registration numbers}

EUDRA CT 2015-001973-42, NCT00168701, NCT00420212, NCT00451451, and NCT00835770.

\author{
Correspondence \\ Dr. Mehta \\ devangi.mehta@biogen.com \\ or Dr. Miller \\ catherine.miller@ \\ biogen.com
}

\section{RELATED ARTICLE}

\section{Editorial}

Dimethyl fumarateinduced changes in the MS lymphocyte repertoire: No need for subset monitoring Page 696

\footnotetext{
*These authors contributed equally to the manuscript
}

From Biogen (D.M., C.M., E.B., J.H., S.L., A.M., C.A.v.H., L.Y.), Cambridge, MA; NeuroRx Research (D.L.A.), Montreal; Montreal Neurological Institute (D.L.A.), McGill University, Montreal, Canada; Center for Neuroinflammation and Experimental Therapeutics and Department of Neurology (A.B.-O.), Perelman School of Medicine, University of Pennsylvania, Philadelphia; Department of Neurology (R.G.), St. Josef Hospital, Ruhr University, Bochum, Germany; Department of Neurology (L.K.), University Hospital Basel, Switzerland; University of New Mexico Health Sciences Center (J.T.P.), Albuquerque; Department of Neurology, Multiple Sclerosis Division (D.R.), Morsani College of Medicine, University of South Florida, Tampa; Mellen Center for Multiple Sclerosis, Neurological Institute (R.J.F.), Cleveland Clinic, OH; Envision Pharma Group (J.C.), Sydney, Australia; and Envision Pharma Group (K.S.), Southport, CT.

Go to Neurology.org/N for full disclosures. Funding information and disclosures deemed relevant by the authors, if any, are provided at the end of the article. The Article Processing Charge was funded by Biogen.

The Article Processing Charge was funded by Biogen.

This is an open access article distributed under the terms of the Creative Commons Attribution-NonCommercial-NoDerivatives License 4.0 (CC BY-NC-ND), which permits downloading and sharing the work provided it is properly cited. The work cannot be changed in any way or used commercially without permission from the journal. 


\section{Glossary}

$\mathrm{AE}=$ adverse event; $\mathbf{A L C}=$ absolute lymphocyte count $\mathbf{C B C}=$ complete blood cell count; $\mathbf{C F B}=$ change from baseline; CONFIRM = Efficacy and Safety Study of Oral BG00012 With Active Reference in Relapsing-Remitting Multiple Sclerosis; DEFINE = Efficacy and Safety of Oral BG00012 in Relapsing-Remitting Multiple Sclerosis; DMF = delayed-release dimethyl fumarate; ENDORSE = BG00012 Monotherapy Safety and Efficacy Extension Study in Multiple Sclerosis; Ig = immunoglobulin; LLN = lower limit of normal; NK = natural killer; PML = progressive multifocal leukoencephalopathy; RRMS = relapsing-remitting multiple sclerosis; SAE $=$ serious adverse event; $\mathrm{Th}=\mathrm{T}$ helper.

Delayed-release dimethyl fumarate (DMF) is an oral treatment approved for patients with relapsing-remitting multiple sclerosis (RRMS). In patients treated with DMF, absolute lymphocyte count (ALC) decline typically occurs within the first year of treatment and stabilizes. ${ }^{1}$ Early ALC drops have been associated with later development of severe, prolonged lymphopenia (ALC $<0.5$ $\times 10^{9} / \mathrm{L}$ for $>6$ months) while on treatment; however, degree of change in ALC is not indicative of response, as patients with and without lymphopenia demonstrated similar reductions in relapse rate vs placebo in pivotal trials. ${ }^{1-3}$ In addition, no overall increased incidence of serious infection, including opportunistic infections, was observed with DMF vs placebo in the controlled pivotal trials. ${ }^{2-5}$ Rare cases of progressive multifocal leukoencephalopathy (PML) associated with DMF usage have been reported in the presence of moderate to severe, prolonged lymphopenia. ${ }^{6}$

Preliminary data indicate that DMF-associated lymphopenia results in a shift in immunophenotype, causing a reduction in circulating central and effector memory $\mathrm{T}$ cell number and concomitant increase in naive $\mathrm{T}$ cells. ${ }^{7-9}$ We present data from an integrated analysis of long-term data from DMF clinical studies (BG00012 Monotherapy Safety and Efficacy Extension Study in Multiple Sclerosis [ENDORSE] integrated analysis) and 6-month interim findings from a prospective trial (PROCLAIM) to evaluate the early dynamics of the lymphocyte repertoire and compare patients with longterm DMF exposure and varying degrees of lymphopenia to further understand the effect of these changes on the benefit-risk profile of DMF.

\section{Methods}

\section{Study design and participants}

\section{PROCLAIM analysis}

PROCLAIM (EUDRA CT 2015-001973-42 [clinicaltrialsregister.eu/ctr-search/search?query=2015-001973-42]; 6-month interim analysis) is an ongoing, prospective, openlabel, 96-week, phase 3b study evaluating DMF $240 \mathrm{mg}$ 2 times daily (BID) in adult patients aged 18-65 years with RRMS. Lymphocyte subset dynamics were characterized within the first 6 months of DMF treatment for patients from PROCLAIM. Key patient inclusion criteria included age
18-65 years and a RRMS diagnosis (McDonald criteria). ${ }^{10}$ The main exclusion criteria were previous exposure to DMF; positive serology for HIV or hepatitis B or C; history of drug or alcohol abuse within 1 year before screening; any clinically significant infectious illness within 30 days of screening; a history of clinically significant comorbid disorders or conditions; leukocytes $<3.5 \times 10^{9} / \mathrm{L}$, ALC values $\leq$ lower limit of normal (LLN, $\left.0.91 \times 10^{9} / \mathrm{L}\right)$, or alanine transaminase/serum glutamic pyruvic transaminase or aspartate transaminase/serum glutamic oxaloacetic transaminase $\geq 2 \times$ the upper limit of normal at screening; or exposure to cyclosporine, azathioprine, methotrexate, mycophenolate mofetil, IV immunoglobulin (Ig), plasmapheresis, or another investigational drug within 6 months of baseline. Patients with $\geq 6$ months of follow-up or who discontinued study treatment at any time point were included in this analysis.

Blood samples were collected at baseline and every 4 weeks for the first 3 months, followed by every 12 weeks through the first year, every 24 weeks in the second year, and at the last follow-up visit, for a total of 104 weeks. An analysis of the major lymphocyte subsets and functional phenotypes of each subset was performed to characterize the dynamics of changes in the immune cell repertoire during early DMF treatment in patients participating in PROCLAIM who had $\geq 24$ weeks of follow-up or who discontinued study treatment at any time point.

The primary endpoint of PROCLAIM is the change in lymphocyte subsets over the initial 48 weeks of DMF treatment. Secondary and exploratory endpoints included the change in ALC and Ig antibodies over 48 weeks of DMF treatment and safety. Safety was measured by adverse events (AEs) and serious AEs (SAEs) and based on the 24-week interim analysis.

\section{ENDORSE integrated analysis}

An integrated analysis of the phase $2 \mathrm{~b}$ study (NCT00168701 [clinicaltrials.gov/ct2/show/NCT00168701]), pivotal phase 3 Efficacy and Safety of Oral BG00012 in Relapsing-Remitting Multiple Sclerosis (DEFINE) (NCT00420212 [clinicaltrials. gov/ct2/show/NCT00420212]), Efficacy and Safety Study of Oral BG00012 With Active Reference in Relapsing-Remitting Multiple Sclerosis (CONFIRM) (NCT00451451 [clinicaltrials. gov/ct2/show/NCT00451451]) studies, and the ongoing phase 
3 ENDORSE (NCT00835770 [clinicaltrials.gov/ct2/show/ NCT00835770]) extension study of the DEFINE/CONFIRM parent studies was conducted to assess long-term data, referred to as the ENDORSE integrated analysis throughout this article. Data starting from the first exposure to DMF are included in the analysis. The data cutoff date for ENDORSE was October 1, 2016. Details about study designs and objectives for DEFINE/ CONFIRM have been published previously. ${ }^{2-4,11}$

During the ENDORSE extension study, patients who had received DMF $240 \mathrm{mg}$ BID or 3 times daily in the parent studies continued with this dosage, and those receiving placebo (DEFINE/CONFIRM) or glatiramer acetate (CONFIRM) were re-randomized 1:1 to DMF $240 \mathrm{mg}$ BID or 3 times daily. Following marketing authorization of DMF, all patients switched to open label DMF $240 \mathrm{mg}$ BID.

Changes in ALC were assessed using blood samples collected at baseline and throughout treatment with DMF. ALC data were collected at baseline and every 4 weeks (phase $2 b$ ), every 4 weeks for the first 3 months, and every 12 weeks thereafter for 2 years (DEFINE/CONFIRM), and at least every 12 weeks for up to 12 years (ENDORSE).

For patients in ENDORSE who discontinued DMF for any reason, and had an ALC < LLN at their last study visit, blood samples were collected every 12 weeks for 48 weeks after their last dose, or until ALC was $\geq$ LLN, whichever was earlier. Similar to the on-treatment ALC monitoring schedule, the introduction of a stopping rule, which required patients to discontinue treatment if severe, prolonged lymphopenia had occurred, was introduced after the study had been initiated and was applied retrospectively, thus the on-treatment duration of lymphopenia varies for patients who discontinued therapy with DMF and remained on-treatment for ALC follow-up.

The ENDORSE integrated analysis of lymphocyte subsets is cross-sectional in nature, and the first samples for the exploratory subset analysis were collected after all active patients had been in ENDORSE for at least $\sim 4$ years. For this analysis, patients with an ALC $\geq$ LLN had a single blood sample taken, patients with an ALC $>0.5$ to $0.91 \times$ $10^{9} / \mathrm{L}$ had blood samples collected every 12 weeks, and patients with an ALC $\leq 0.5 \times 10^{9} / \mathrm{L}$ had blood samples collected every 4 weeks. This cross-sectional analysis was performed using blood samples from the first time point that both hematology and flow cytometry were performed. Thus, the actual duration of DMF exposure varies for each patient.

The primary objective of ENDORSE is to evaluate the longterm safety profile of DMF. Exploratory objectives include evaluating the effects of DMF on lymphocyte subsets, as well as describing lymphocyte reconstitution after discontinuation of DMF.
Hematology and flow cytometric analyses

ALC were measured by routine clinical laboratory studies using complete blood count (CBC) differential procedure. Immune cell subsets were quantified in whole blood by multiparameter flow cytometry analysis (table e-1; doi.org/10.5061/dryad.d065rr9). Fluorescence-activated cell scanning assays were designed based on Human Immunophenotyping Consortium-recommended standardized immunophenotyping panels ${ }^{12}$ and were optimized and validated for whole blood sample analysis with sample stability in sodium heparin vacutainers established for up to 48-72 hours post collection (table e-2; doi.org/10. 5061/dryad.d065rr9). Data acquisition was performed by LabCorp Clinical Trials on a BD FACSCanto II (BD Biosciences, San Jose, CA) flow cytometer.

\section{Statistical analysis}

\section{PROCLAIM}

For the longitudinal PROCLAIM analysis, the change in lymphocyte subsets during DMF treatment over 24 weeks and the median (25\%, $75 \%$ quartiles) percentage change from baseline at week 24 were calculated. The corresponding $p$ values were calculated using Wilcoxon signed rank test. Mean and standard error were calculated for Ig antibodies.

\section{ENDORSE integrated analysis}

A comprehensive analysis of the safety profile of DMF was assessed for patients in the ENDORSE integrated analysis with the use of descriptive statistics for the safety population (all patients who received $\geq 1$ dose of the study drug) to calculate incidence of AEs and SAEs.

Change in ALC over time also was assessed for the ENDORSE integrated analysis, but only included patients with a baseline ALC, and $\geq 1$ ALC recorded during treatment. Moderate, prolonged lymphopenia was defined as ALC $0.5-<0.8 \times 10^{9} / \mathrm{L}$ for $\geq 6$ months and severe, prolonged lymphopenia as ALC $<0.5 \times 10^{9} / \mathrm{L}$ for $\geq 6$ months. The assessment of lymphocyte subsets was limited to only patients in ENDORSE. Patients were analyzed according to ALC category. The correlation between ALC and $\mathrm{CD} 4^{+}$and $\mathrm{CD} 8^{+} \mathrm{T}$-lymphocyte counts was assessed using Pearson and Spearman correlation coefficients.

For the analysis of ALC following DMF discontinuation, patients were eligible for inclusion in the analysis if they had $\geq 1$ ALC recorded following the discontinuation of DMF, regardless of reason for discontinuation.

\section{Standard protocol approvals, registrations, and patient consents}

Studies were approved by the relevant institutional review board for each study site, and each study was conducted in accordance with the Declaration of Helsinki, International Conference of Harmonisation-Good Clinical Practice guidelines, and all applicable laws and regulations. All 
participants provided written informed consent before study procedures.

\section{Data availability}

PROCLAIM, the phase 2b study, DEFINE, CONFIRM, and ENDORSE were registered with ClinicalTrials.gov (EUDRA CT 2015-001973-42, NCT00168701, NCT00420212, NCT00451451, and NCT00835770). Requests for data supporting this article should be submitted to the Biogen Clinical Data Request Portal (biogenclinicaldatarequest.com).

\section{Results}

\section{Demographic and baseline clinical characteristics}

For the PROCLAIM analysis of the first 6 months of DMF treatment, 163 patients were included in the interim analysis (table 1). Demographic and baseline characteristics for the 2,513 patients were broadly consistent among all 4 studies in the ENDORSE integrated analysis, as previously presented. $^{2-4,11}$ Patients in PROCLAIM were older compared with those in DEFINE/CONFIRM; 62\% of patients in PROCLAIM were aged $\geq 40$ years at the time of enrollment, compared with $46 \%$ in the ENDORSE integrated analysis. The mean (SD) duration of DMF treatment was 30.2 (10.3) weeks for patients in PROCLAIM and 201 (154) weeks for the ENDORSE integrated analysis.

\section{Lymphocytes}

\section{Monitoring of ALCs}

For the ALC analysis, 2,470 patients had $\geq 1$ postbaseline ALC value and therefore were included in the ENDORSE integrated analysis. The pattern of initial decline followed by stabilization of ALC after week 24 was generally maintained during 10 years of follow-up in ENDORSE, and the majority $(60.2 \%)$ of patients remained $>$ LLN $\left(0.91 \times 10^{9} / \mathrm{L}\right.$; figure 1A). Patients with moderate, prolonged lymphopenia remained on treatment for mean (SD) of 4.0 (2.3) years; 2.9 (1.7) years for patients with severe, prolonged lymphopenia.

In PROCLAIM, median ALC was $1.82 \times 10^{9} / \mathrm{L}$ at baseline and $1.24 \times 10^{9} / \mathrm{L}$ at week 24 , representing a median $-33.6 \%$ change from baseline (figure 2), with reductions observed as early as week 4. Patients will continue to be followed through year 2 to assess the long-term dynamics of ALC.

\section{Dynamics of lymphocyte subset changes during early DMF treatment}

In PROCLAIM, the number of circulating major lymphocyte subsets declined following initiation of DMF treatment, consistent with the decline in ALC (figure 2). B-cell counts initially experienced the greatest rate and proportion of decline, detected as early as 4 weeks after initiation of treatment $(-10.4 \%$ median change from baseline [CFB], $p<0.0001)$, before reaching their nadir after 12 weeks $(-29.9 \%$ median CFB, $p<0.0001$ ), remaining below baseline. By week 8 , reduced circulating numbers of $\mathrm{CD}^{+}$and $\mathrm{CD}^{+} \mathrm{T}$ and natural killer (NK) cells were observed (median CFB, $p$ value: $-12.6 \%, p<0.0001$; $-16.4 \%, p<0.0001$; and $-6.1 \%$, NS). Consistent with the pattern in B cells, the decline in NK cell counts appeared to stabilize after 12 weeks $(-11.2 \%$ median $\mathrm{CFB}, p=0.001)$, remaining below normal, whereas $\mathrm{CD}^{+}$and $\mathrm{CD}^{+} \mathrm{T}$ cell counts continued to decline from baseline through week 24 and $\mathrm{CD}^{+} \mathrm{T}$ cells had the greatest median percentage reduction. By week 24, evidence of a disproportionate effect on $\mathrm{T}$-cell subsets was observed; $\mathrm{CD}^{+} \mathrm{T}$ cells demonstrated a $25 \%$ greater relative decline than $\mathrm{CD}^{+}$ $\mathrm{T}$ cells from baseline $\left(\mathrm{CD}^{+}:-44 \%\right.$; $\mathrm{CD}^{+}:-33 \%, p<$ $0.0001)$. Monocyte and granulocyte cell counts significantly increased during the first 24 weeks of treatment, though only slightly $(<10 \%, p<0.001)$.

Each major lymphocyte subset (T, B, and NK cells) was further characterized by refined immunophenotyping of functional subsets as depicted in figure 3. As expected, a reduction in the absolute counts of functional subsets was observed at week 24, with the greatest median percentage reduction from baseline in $\mathrm{T}$ - and $\mathrm{B}$-cell memory populations and the least effect on naive T- and B-cell subsets (figure 3). While the greatest median percentage reduction by 24 weeks was observed in $\mathrm{CD}_{138^{+}}$plasma cells $(-100 \%, p<0.0001)$, this also is the most difficult population to reliably and accurately measure due to normally very low circulating numbers. ${ }^{13}$ However, the overall reduction in the terminally differentiated plasma cell population is supported by the concomitant reduction of circulating $\mathrm{CD} 27^{+}$memory B cells, both nonclass-switched $\left(\mathrm{CD} 27^{+} \mathrm{IgD}^{+}\right)$and class-switched $\left(\mathrm{CD} 27^{+} \mathrm{IgD}^{-}\right)$subsets. Notably, among $\mathrm{T}$ cells, the greatest median percentage reduction by week 24 was observed in the memory T-cell compartment: central memory (CD45RA ${ }^{-}$/ $\left.\mathrm{CCR}^{+}\right) \mathrm{CD}^{+} \mathrm{T}$ cells $(-73 \%, p<0.0001)$, effector memory $\left(\mathrm{CD}_{5} \mathrm{RA}^{-} / \mathrm{CCR}^{-}\right) \mathrm{CD}^{+} \mathrm{T}$ cells $(-65 \%, p<0.0001)$, and effector memory $\left(\mathrm{CD}^{2} 5 \mathrm{RA}^{-} / \mathrm{CCR}^{-}\right) \mathrm{CD}^{+} \mathrm{T}$ cells $(-61 \%$, $p<0.0001)$. Substantial reductions in absolute counts of $\mathrm{T}$ helper (Th) $1\left(\mathrm{CXCR}^{+} / \mathrm{CCR}^{-}\right)$and Th17 (CXCR3 ${ }^{-}$/ $\mathrm{CCR}^{+}{ }^{+} \mathrm{CD}^{+} \mathrm{T}$ cells also were observed compared with the Th2-enriched population ( $\left.\mathrm{CXCR} 3^{-} / \mathrm{CCR}^{-}\right)$. The numbers of naive $\left(\mathrm{CD}_{5} \mathrm{RA}^{+} / \mathrm{CCR}^{+}\right) \mathrm{CD}^{+}(-7 \%, \mathrm{NS})$ and $\mathrm{CD} 8^{+}$ $(-29 \%, p<0.0001) \mathrm{T}$ cells, as well as naive regulatory $\left(\mathrm{CD} 25^{+} / \mathrm{CD} 127^{\text {low } /-}\right) \mathrm{CD}^{+} \mathrm{T}$ cells $(0 \%, p<0.05)$, were least affected by DMF treatment by week 24 . Interestingly, only 2 populations expanded during DMF treatment by week 24: the numbers of transitional (CD2 $4^{\text {high }} \mathrm{CD} 38^{\text {high }}$ ) B cells $(+29 \%, p<0.0001)$ and CD56 ${ }^{\text {bright }} \mathrm{NK}$ cells $(+25 \%, p<$ $0.0001)$.

In addition to assessing the changes in lymphocyte subset numbers, the functional composition of the remaining lymphocyte repertoire was evaluated by assessing the relative proportions of each subset population. Within both $\mathrm{CD}^{+}$ and $\mathrm{CD}^{+} \mathrm{T}$-cell compartments, at week 24 , there was a significant relative decrease in the proportion of central memory and effector memory phenotypes and a corresponding 
Table 1 Patient demographics and disease characteristics

\begin{tabular}{|c|c|c|}
\hline Characteristic & PROCLAIM, n = 163 & $\begin{array}{l}\text { ENDORSE integrated analysis, } \\
n=2,513\end{array}$ \\
\hline Age, y, mean (SD) & $43(11)$ & $38(9)$ \\
\hline Age $\geq 40$ y, $n$ (\%) & $101(62)$ & $1,167(46)$ \\
\hline Female, n (\%) & $113(69)$ & $1,764(70)$ \\
\hline Body mass index, mean (SD) & $28(8)$ & $25(9)$ \\
\hline \multicolumn{3}{|l|}{ Country, n (\%) } \\
\hline Region $1^{a}$ & $68(42)$ & $388(15)$ \\
\hline Region $2^{b}$ & $1(<1)$ & $681(27)$ \\
\hline Region $3^{c}$ & $94(58)$ & $1,444(57)$ \\
\hline \multicolumn{3}{|c|}{ Baseline lymphocyte level $\left(\times 10^{9} / L\right)$, mean $(S D)^{d}$} \\
\hline Lymphocytes & $1.8(0.7)$ & $1.3(0.7)$ \\
\hline T cells & $1.3(0.5)$ & $0.9(0.5)$ \\
\hline $\mathrm{CD}^{+} \mathrm{T}$ cells & $0.9(0.4)$ & $0.6(0.4)$ \\
\hline $\mathrm{CD}^{+} \mathrm{T}$ cells & $0.4(0.2)$ & $0.2(0.2)$ \\
\hline B cells & $0.2(0.2)$ & $0.2(0.3)$ \\
\hline NK cells & $0.2(0.1)$ & $0.2(0.1)$ \\
\hline Time since MS diagnosis, y, mean (SD) & $7.0(6.7)$ & $5.5(5.3)$ \\
\hline No. of relapses in prior year, mean (SD) & $0.8(0.8)$ & $1.3(0.7)$ \\
\hline Baseline EDSS score, mean (SD) & $2.8(1.5)$ & $2.5(1.3)$ \\
\hline Baseline EDSS score $>2.0, \mathrm{n}(\%)$ & $91(56)$ & $1,291(51)$ \\
\hline Duration of treatment, wk, mean (SD) & $30.2(10.3)$ & $201(154)$ \\
\hline Any prior DMT, n (\%) & $112(69)$ & $814(32)$ \\
\hline \multicolumn{3}{|l|}{ Prior MS treatment, $\mathbf{n}(\%)$} \\
\hline Glatiramer acetate & $43(26)$ & $129(5)$ \\
\hline Interferon- $\beta-1 \mathrm{a}$ & $50(31)$ & $412(16)$ \\
\hline Interferon- $\beta-1 b$ & $25(15)$ & $203(8)$ \\
\hline Natalizumab & $8(5)$ & $34(1)$ \\
\hline Other & $43(38)$ & $379(15)$ \\
\hline
\end{tabular}

Abbreviations: DMT = disease-modifying therapy; EDSS = Expanded Disability Status Scale; ENDORSE = BG00012 Monotherapy Safety and Efficacy Extension Study in Multiple Sclerosis; MS = multiple sclerosis; NK = natural killer.

Demographics are shown at baseline for PROCLAIM and the last visit on or before the first exposure to dimethyl fumarate for the integrated analysis.

${ }^{a}$ Region 1 includes United States (including Puerto Rico).

${ }^{b}$ Region 2 includes Western European countries (Austria, Belgium, France, Germany, Greece, Ireland, Italy, Netherlands, Spain, Sweden, Switzerland, and United Kingdom), Australia, Canada, Costa Rica, Israel, New Zealand, and South Africa. PROCLAIM patients were from Belgium only, within Region 2.

'Region 3 includes Eastern European countries (Belarus, Bosnia and Herzegovina, Bulgaria, Croatia, Czech Republic, Estonia, Hungary, Latvia, Macedonia, Moldova, Poland, Romania, Russia, Serbia, Slovakia, Turkey, and Ukraine), Guatemala, India, and Mexico. PROCLAIM patients were from Bulgaria, Lithuania, or Poland only, within Region 3.

${ }^{d} \mathrm{n}=745$ patients for the ENDORSE integrated analysis; data summarized are at the first visit with flow cytometry collected after flow cytometry was added to study as amendment.

significant increase in the naive phenotype (figure 4, A and B). While the proportion of effector $\mathrm{CD} 8^{+} \mathrm{T}$ cells was only slightly reduced by week 24 , the proportion of $\mathrm{CD}^{+} \mathrm{T}$ cells with an activated phenotype $\left(\mathrm{CD} 38^{+} \mathrm{HLADR}^{+}\right)$significantly increased compared with baseline $(51 \%$, median CFB, $p<0.0001)$. Similarly, the proportion of $\mathrm{CD}^{+} \mathrm{T}$ cells with an activated phenotype $\left(\mathrm{CD} 38^{+} \mathrm{HLADR}^{+}\right)$also increased (17\% median CFB at week 24, $p<0.0001$ ). Importantly, the relative proportion of the total regulatory $\mathrm{T}$ cells among the $\mathrm{CD}^{+}{ }^{+} \mathrm{T}$-cell population was stable during DMF treatment (7.7\% median CFB at week 24, $p<0.0001$ ) (figure 4C). Correspondingly, there was a relative decline in the proinflammatory 
Figure 1 Absolute lymphocyte counts (ALCS) over 8 years of dimethyl fumarate (DMF) treatment and lymphocyte subsets by ALC categories

A

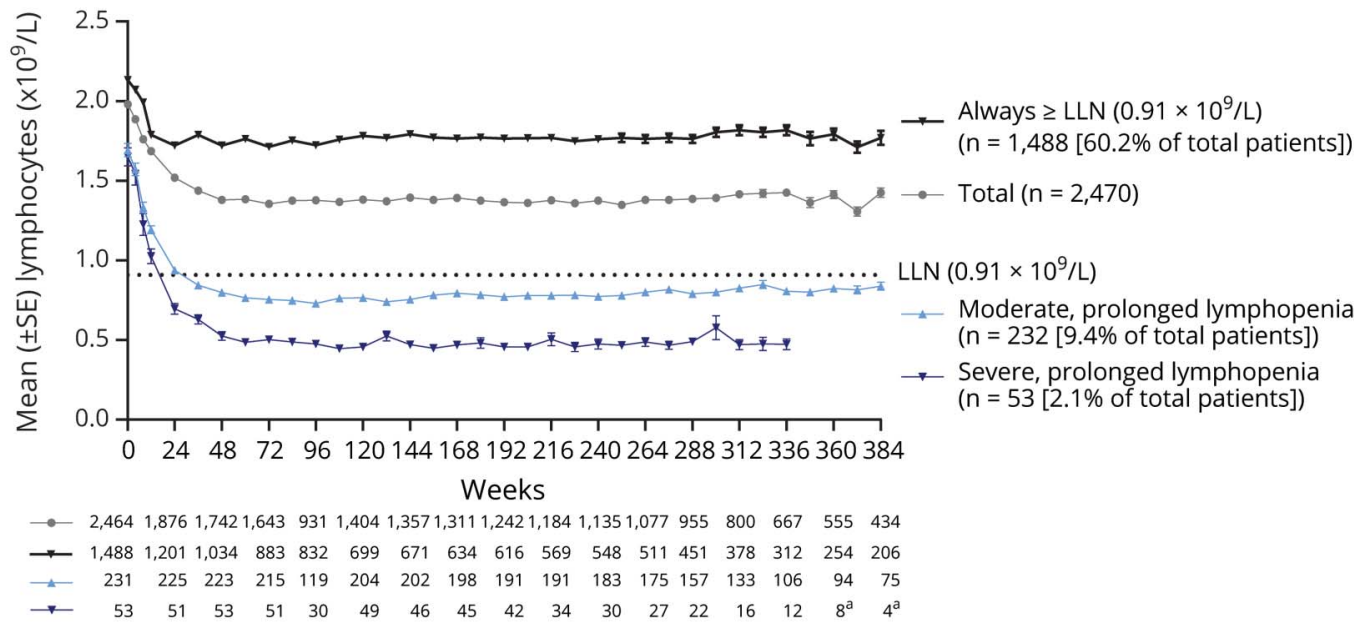

B

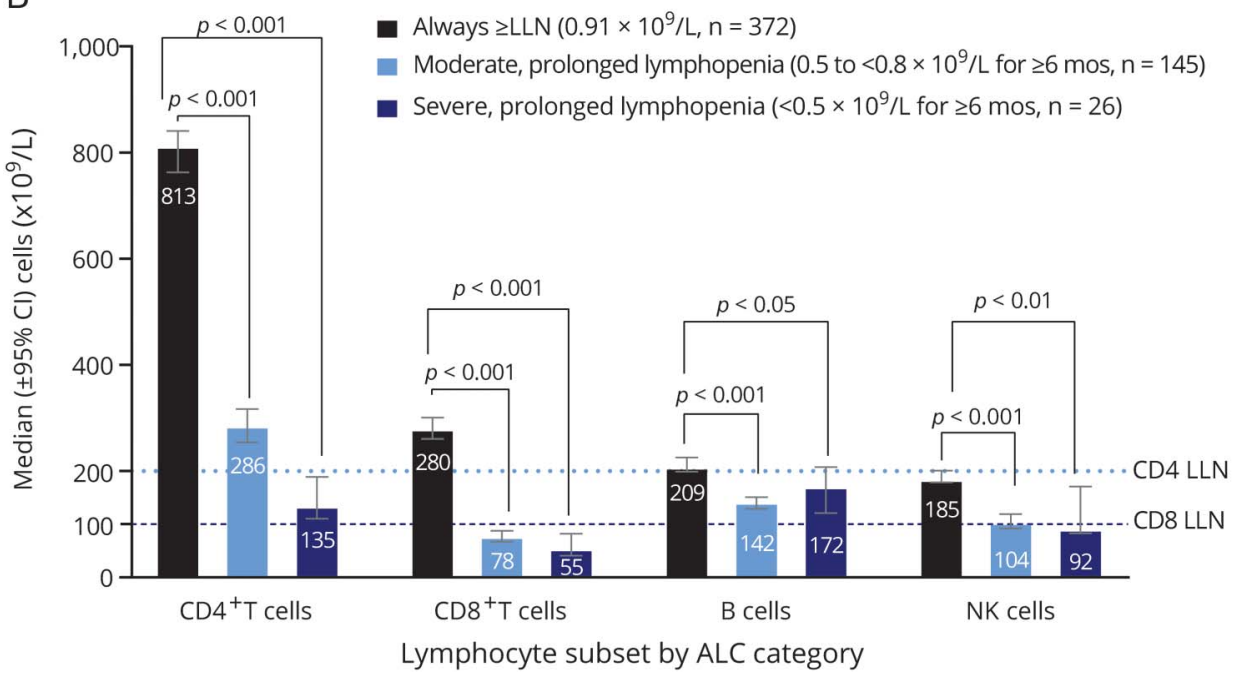

(A) ALCS over 8 years of DMF treatment. Mean $\left( \pm\right.$ SE) and $95 \%$ confidence intervals $(\mathrm{Cls})$ are presented $(n=2,470)$. Lower limit of normal $(\mathrm{LLN})\left(0.91 \times 10^{9} / \mathrm{L}\right)$ is signified by the dotted line. ${ }^{a}$ Data not presented for $<10$ patients. (B) Lymphocyte subsets by ALC categories CD4 $4^{+} \mathrm{LLN}=0.2 \times 10^{9} / \mathrm{L} ; \mathrm{CD} 8^{+} \mathrm{LLN}=0.1 \times 10^{9} / \mathrm{L}$. Median (values inside the bars) and $95 \% \mathrm{Cls}$ are presented. Data were stratified by all ALCs collected during the study (ALC 0.5 to $<0.8 \times 10 \% / \mathrm{L}$ for $\geq 6$ months [moderate, prolonged lymphopenia]; ALC $<0.5 \times 10^{9} / \mathrm{L}$ for $\geq 6$ months [severe, prolonged lymphopenia]; ALC always $\geq 0.91 \times 10^{9} / \mathrm{L}$ [always $\geq$ LLN]). Patients were categorized as having moderate to severe prolonged lymphopenia if they met these criteria at any time during the study. NK $=$ natural killer.

Th1 and Th17 subsets (figure 4C) and an increase in the Th2-enriched phenotype. Among the B-cell compartment, the relative proportion of transitional and naive $\mathrm{B}$ cells increased while nonclass switched $\left(\mathrm{IgD}^{+}\right)$and class switched $\left(\operatorname{IgD}^{-}\right)$memory B-cell subsets significantly decreased from baseline to week 24 (figure 5A). Finally, in the immunoregulatory $\mathrm{CD} 56^{\text {bright }} \mathrm{NK}$ cell population, there was both an absolute $(25 \%$ median CFB, $p<0.0001)$ and relative $(87 \%$ median CFB at week $24, p<0.0001)$ increase (figures 3 and $5 \mathrm{~B}$ ). Overall, DMF treatment appears to selectively modulate proinflammatory and antigen-experienced lymphocytes, with many of these changes observed as early as 4 weeks after DMF initiation. In a parallel assessment, intracellular cytokine staining was also performed. Due to the analytical variability of the data, these findings are not shown and were not statistically significant; however, the patterns observed were consistent with the cell chemokine receptor-defined T-helper subtypes identified by cell surface staining (e.g., CXCR3).

\section{Lymphocyte subsets by ALC count during long- term DMF treatment}

To assess the long-term effects of DMF on lymphocyte function, as well as to identify any differences in patients with prolonged lymphopenia, a cross-sectional analysis was conducted in ENDORSE patients with at least 4 years of DMF exposure. At the time of the first flow cytometry sample, the 

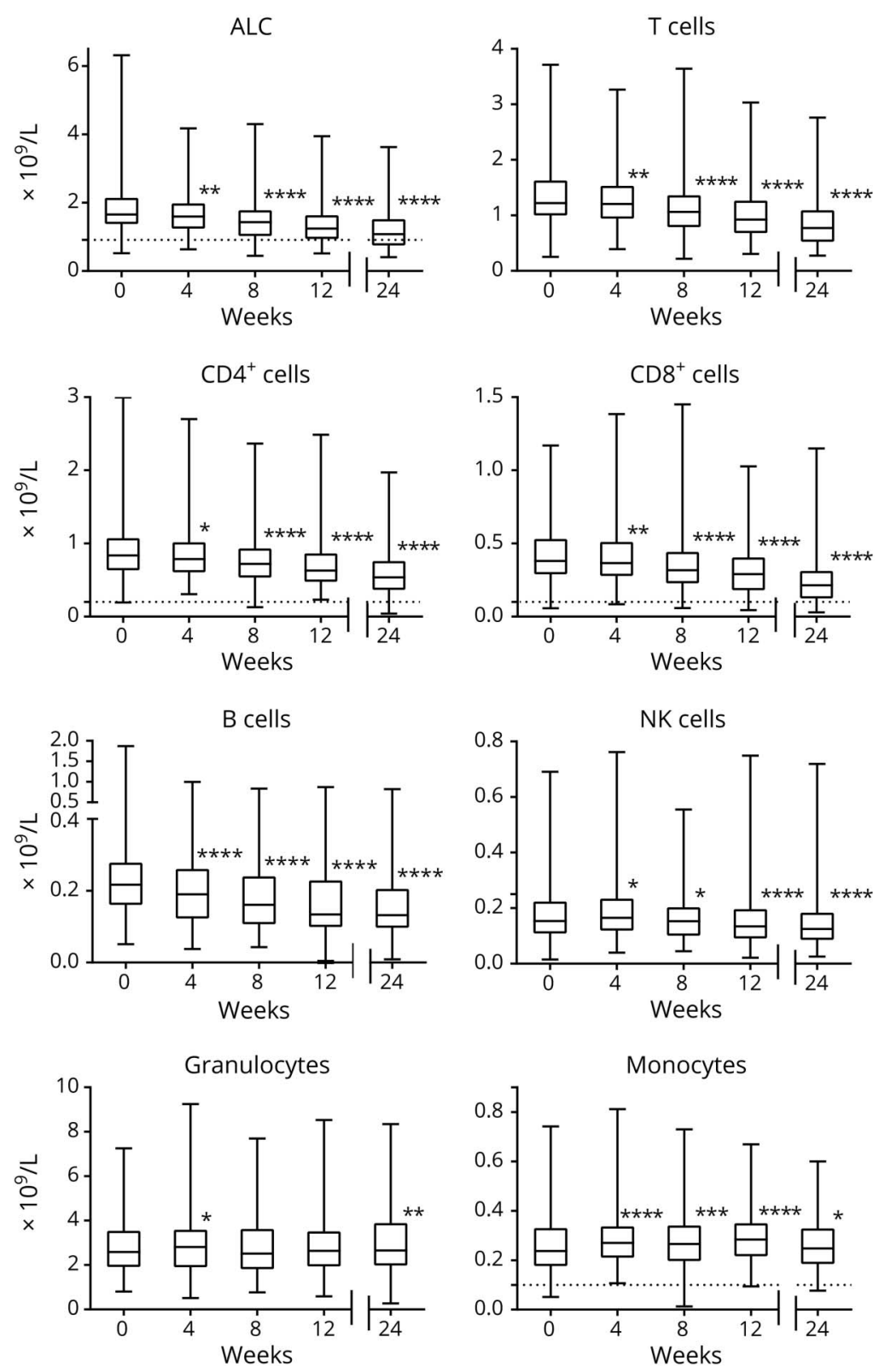

For each box plot, the top and bottom box edges correspond to the first and third quartiles, $n=163$. The black line inside the box represents the median. The top and bottom whisker lines mark the maximum and minimum values of the dataset, respectively. Dotted lines represent lower limit of normal (LLN) (for those subsets with established cutoff values). Absolute lymphocyte count (ALC) $\mathrm{LLN}=0.91 \times 10^{9} / \mathrm{L}$; $\mathrm{CD}^{+} \mathrm{LLN}=0.2 \times 10^{9} / \mathrm{L}^{\prime} \mathrm{CD}^{+} \mathrm{LLN}=0.1 \times 10^{9} / \mathrm{L}^{7,26}$ the corresponding $p$ values were calculated using Wilcoxon signedrank test. Significant $p$ values are marked with asterisks ( ${ }^{*} p$ $<0.05$ vs baseline; $* \star p<0.01$ vs baseline; $* \star \star * p<0.001$ vs baseline; $* * \star * p<0.0001$ vs baseline). NK = natural killer.

mean (SD) exposure to DMF was 6.6 (1.3) years for patients with moderate, prolonged and 6.0 (1.3) years for severe, prolonged lymphopenia. Patients with prolonged moderate $(n=145)$ or severe lymphopenia $(n=26)$, had lower absolute cell counts of $\mathrm{CD}^{+}$and $\mathrm{CD}^{+}{ }^{+} \mathrm{T}-$, B-, and NK cell subsets compared with patients with ALC always above normal ( $\mathrm{n}=372$, figure $1 \mathrm{~B})$. Importantly, there was a high correlation between $\mathrm{CD}^{+}$counts and $\mathrm{ALC}$ and $\mathrm{CD} 8^{+}$ counts and ALC (Spearman correlation coefficient, 0.90 and 0.81 , respectively). Of note, the majority (>50\%) of patients with severe, prolonged lymphopenia had $\mathrm{CD}^{+}$and $\mathrm{CD} 8^{+}$ T-cell counts below $0.2 \times 10^{9} / \mathrm{L}$ and $0.1 \times 10^{9} / \mathrm{L}$, respectively (median, CD $4^{+} \mathrm{T}$-cell count: $0.135 \times 10^{9} / \mathrm{L}$ and $\mathrm{CD}^{+}$T-cell count: $\left.0.055 \times 10^{9} / \mathrm{L}\right)$.
The functional phenotypes for each major lymphocyte subset also were assessed across ALC categories. Overall, the changes to the functional composition of the T-, B-, and NK cell compartments observed early in DMF treatment in PROCLAIM were consistent in patients with long-term DMF exposure in ENDORSE. In an ALC-dependent manner, the relative proportion of the $\mathrm{CD}^{+}$and $\mathrm{CD}^{+}$central memory $\mathrm{T}$ cells declined (table e-3; doi.org/10.5061/dryad.d065rr9) while the proportion of activated $\mathrm{CD} 4^{+}$and $\mathrm{CD}^{+} \mathrm{T}$ cells increased. Within the B-cell compartment, the proportions of transitional and naive B cells increased, while memory B-cell subsets declined further in an ALC-dependent manner. In addition, the proportion of CD56 $6^{\text {bright }}$ and CD $56^{\text {dim }}$ NK cells increased in an ALC-dependent manner. Importantly, across 
Figure 3 Absolute count median percentage change of immune subsets from baseline to week 24 in PROCLAIM

Immune cell subsets

Transitional B cells

Naive B cells

IgD memory B cells (nonclass switched)

Plasmablasts

IgD- memory B cells (class switched)

$\mathrm{CD} 138^{+}$plasma cells

CD56 bright NK cells

CD56 dim NK cells

Naive regulatory $T$ cells

Naive $C D 4^{+} T$ cells

Th2-enriched phenotype

Activated $C D 4^{+} T$ cells

Effector $\mathrm{CD}^{+}{ }^{+}$cells

Regulatory $T$ cells

Effector regulatory $T$ cells

Th17 phenotype

Central memory $C D 4^{+} T$ cells

Th1 phenotype

Effector memory CD4 ${ }^{+} T$ cells

Activated $\mathrm{CD}^{+} \mathrm{T}$ cells

Naive $C D 8^{+} T$ cells

Effector $\mathrm{CD}^{+} \mathrm{T}$ cells

Effector memory $\mathrm{CD}^{+} \mathrm{T}$ cells

Central memory $\mathrm{CD}^{+} \mathrm{T}$ cells
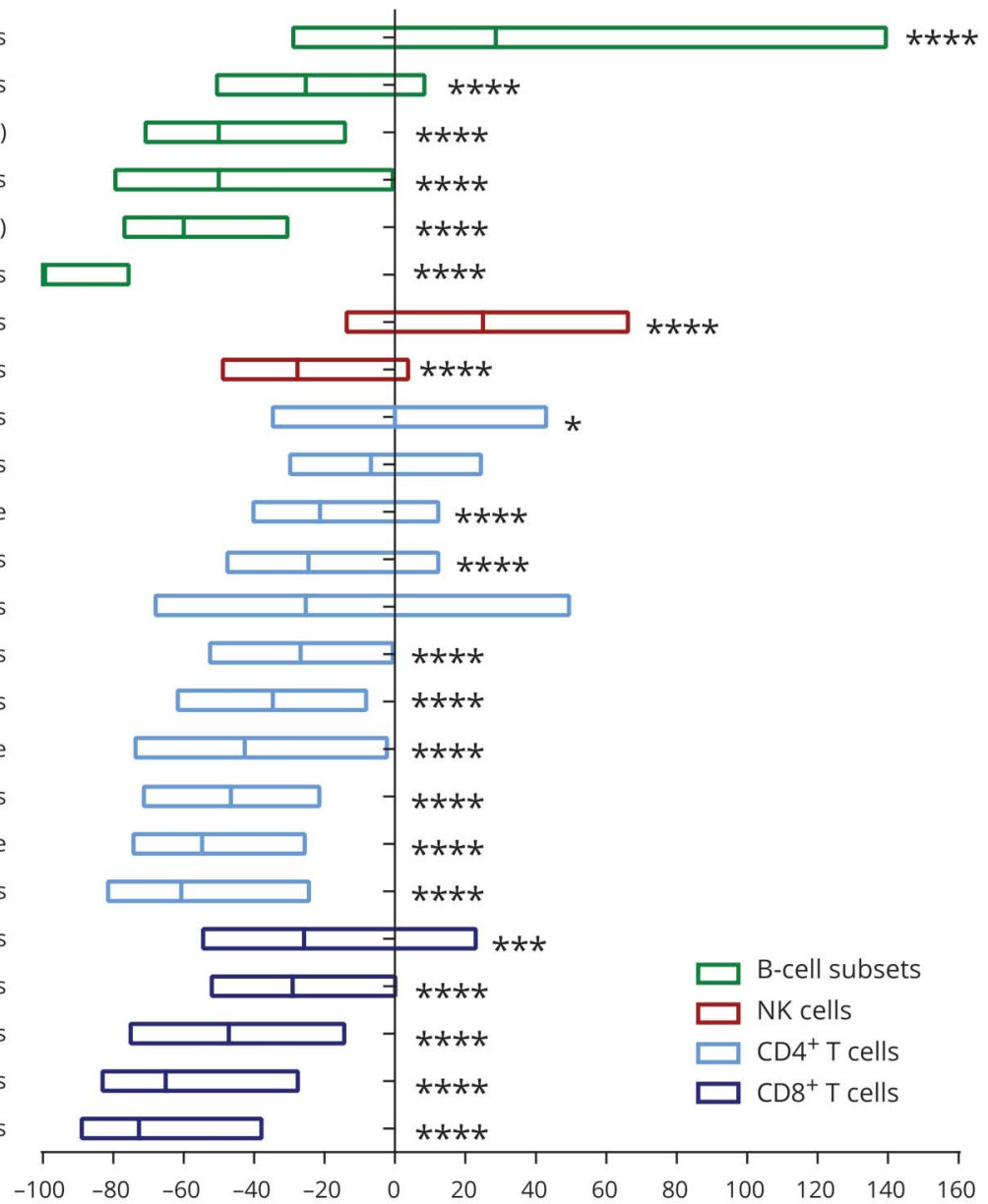

Median (Q1, Q3) percent change from baseline in absolute counts

For each box plot, the top and bottom box edges correspond to Q1 and Q3. The black line inside the box represents the median. The corresponding $p$ values

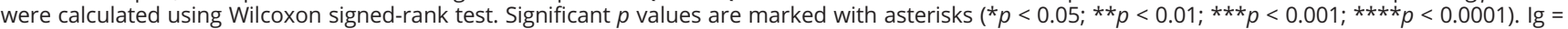
immunoglobulin; NK = natural killer; $\mathrm{Q}=$ quartile; $\mathrm{Th}=\mathrm{T}$ helper

all ALC categories during long-term treatment with DMF, there is a sustained maintenance or increase in the relative proportion of immunoregulatory cells: this includes $\mathrm{CD} 4^{+}$regulatory $\mathrm{T}$, CD56 ${ }^{\text {bright }} \mathrm{NK}$, and potentially transitional B cells, which have a phenotype that overlaps with $\mathrm{IL}-10^{+} \mathrm{B}$ cells, which have been speculated to be implicated in regulatory function. ${ }^{14}$

Interestingly, there were some substantial divergences in the functional immune repertoire specifically among patients with severe, prolonged lymphopenia. Notably, the proportion of naive $\mathrm{CD}^{+}$and $\mathrm{CD}^{+} \mathrm{T}$ cells declined, while the proportion of $\mathrm{CD}^{+}$and $\mathrm{CD}^{+}$effector memory, $\mathrm{CD} 8^{+}$effector, effector regulatory $\mathrm{T}$, and Th1 $\mathrm{T}$ cells increased only among patients with severe, prolonged lymphopenia.

\section{Median percentage changes from baseline in absolute counts and levels of Ig antibodies}

Despite changes in the circulating B-cell repertoire with DMF treatment, there was little to no effect on $\operatorname{IgM}, \operatorname{IgA}, \operatorname{IgG}$, and
IgG subclasses $1-4$ levels by 24 weeks, which remained stable throughout the observation period (figure e-1 and table e-4; doi.org/10.5061/dryad.d065rr9).

\section{Safety}

\section{On-treatment clinical implications of lymphopenia}

For patients who were exposed to DMF for up to 10 years (10,196 total patient-years), the rate of serious infection, herpes zoster infection, and malignancy in the ENDORSE integrated analysis was low overall, and similar across groups when patients were stratified by on-treatment ALC levels (table 2). Likewise, no increased incidence of serious infections or herpes zoster was observed between groups when stratified by ontreatment $\mathrm{CD}^{+}$and $\mathrm{CD}^{+}$T-cell counts (table 2). One opportunistic infection (a fatal case of PML) occurred in the setting of severe lymphopenia (ALC range, $0.3-0.6 \times 10^{9} / \mathrm{L}$ ) of 3.5 years' duration and has been previously reported ${ }^{5}$; there were no other opportunistic infections reported to date. 
Figure 4 Proportions of T-cell subsets during early (PROCLAIM) and long-term (ENDORSE integrated analysis) dimethyl fumarate (DMF) treatment

A
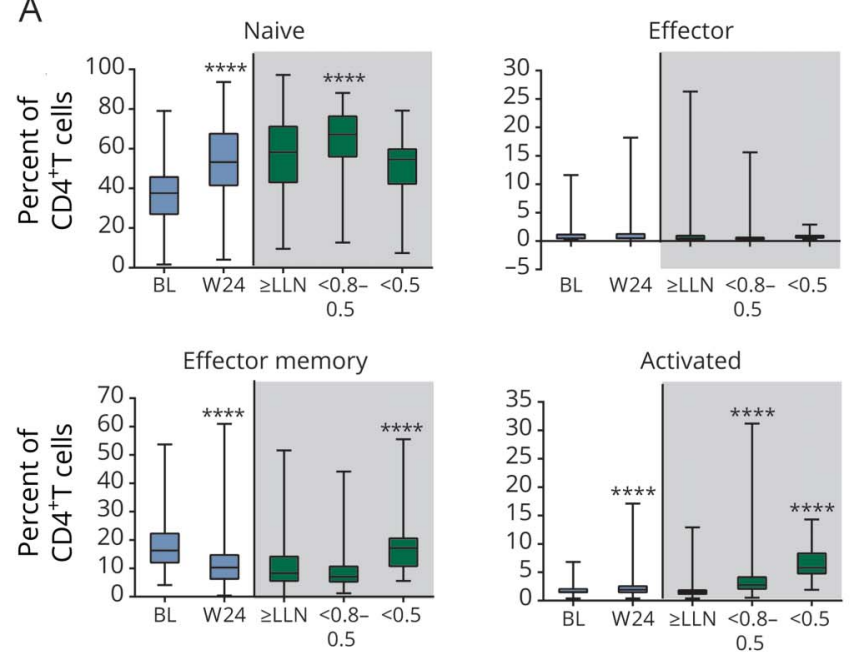

B
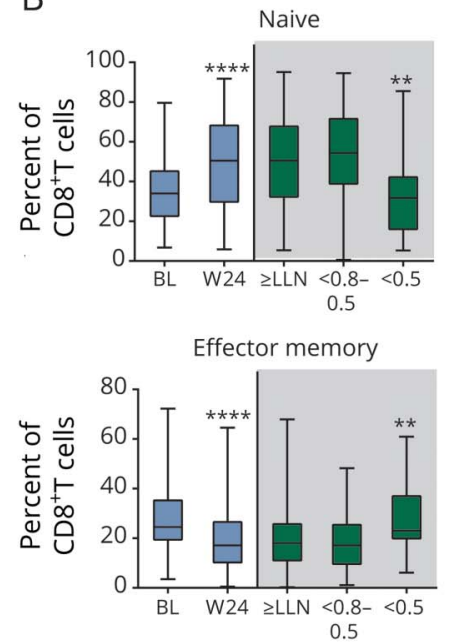

C
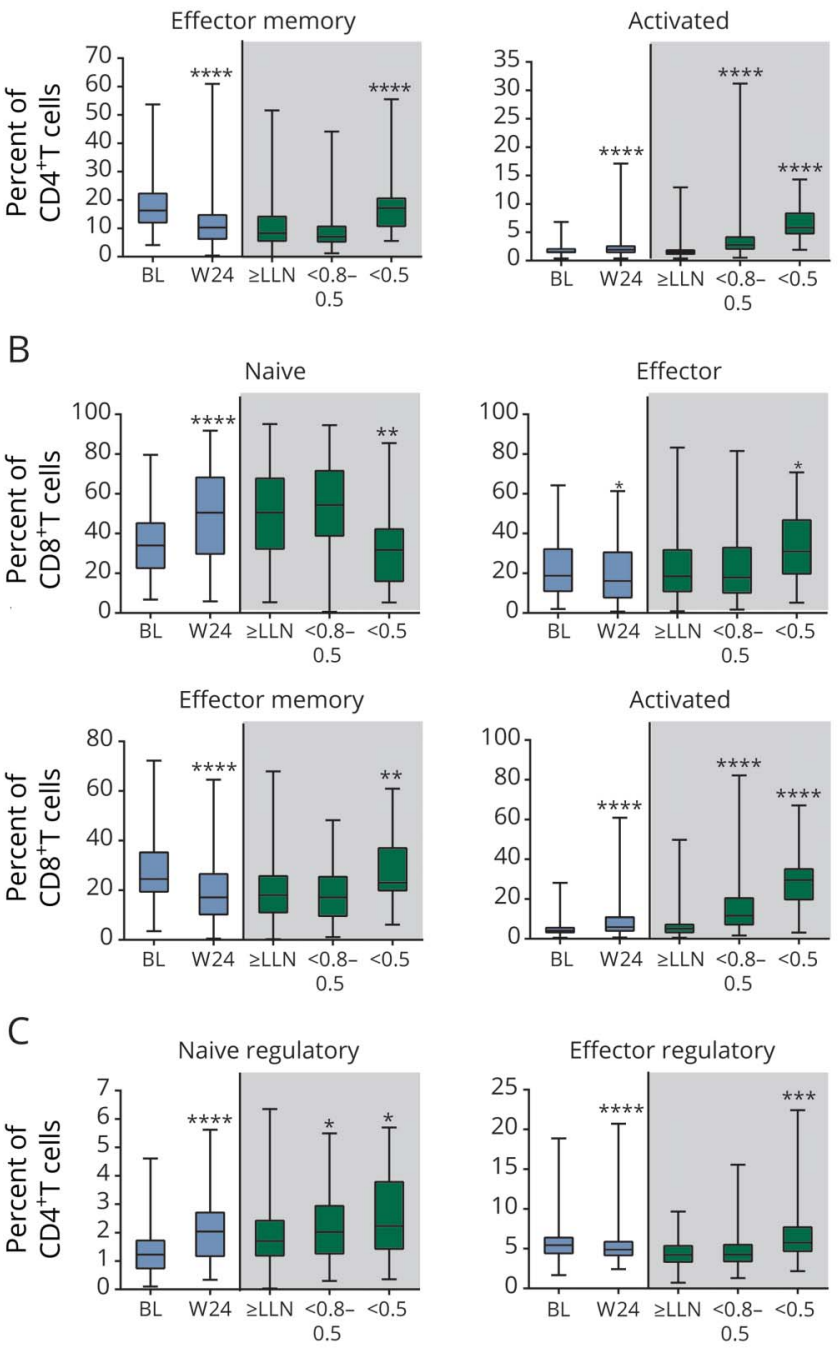

Th2-enriched phenotype

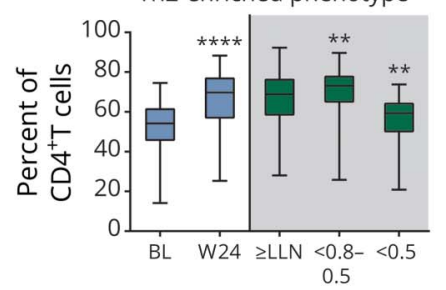

Central memory

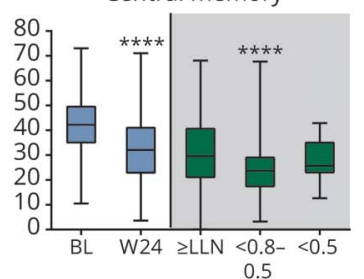

Study visit

ALC category

$\square$ PROCLAIM

ENDORSE

Central memory

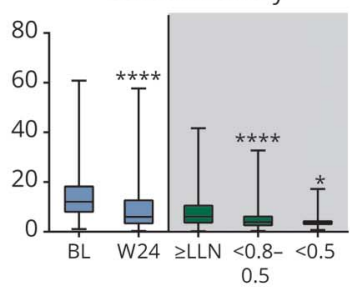

5

PROCLAIM ( $n=163)$ and the BG00012 Monotherapy Safety and Efficacy Extension Study in Multiple Sclerosis (ENDORSE) integrated analysis ( $\mathrm{n}=$ 694) are shown. For each box plot, the top and bottom box edges correspond to the first and third quartiles. The black line inside the box represents the median. The top and bottom whisker lines mark the maximum and minimum values of the dataset, respectively. For PROCLAIM (shaded white), the box plots represent the longitudinal trajectory in lymphocyte subsets during early treatment (from baseline [BL] to week 24 [W24]). For the ENDORSE integrated analysis (shaded gray), the box plots represent the cross-sectional observations in lymphocyte subsets in patients who had been exposed to DMF for $\sim 5$ years, stratified by absolute lymphocyte count (ALC) category. For the ENDORSE integrated analysis, data were stratified by ALC categories (ALC always $\geq 0.91 \times 10^{9} / \mathrm{L}$ [ $\geq$ lower limit of normal (LLN)]; ALC $<0.8-0.5 \times 10^{9} / \mathrm{L}$ for $\geq 6$ months [moderate, prolonged lymphopenia, <0.8-0.5]; ALC <0.5 $\times$ $10^{9} / \mathrm{L}$ for $\geq 6$ months [severe, prolonged lymphopenia, <0.5]). Patients were categorized as having moderate to severe prolonged lymphopenia if they met these criteria at any time during the study. $p$ values were calculated using Wilcoxon signed-rank test, compared the absolute change in relative proportion of lymphocyte subsets at week 24 with baseline for PROCLAIM, were calculated using a pairwise 2-sample Wilcoxon test, and compared the absolute change in relative proportion of lymphocyte subsets for moderate and severe, prolonged lymphopenia compared with ALCS $\geq$ LLN for the BG00012 Monotherapy Safety and Efficacy Extension Study in Multiple Sclerosis (ENDORSE) integrated analysis. Significant $p$ values are marked with asterisks $\left({ }^{*} p<0.05 ; * * p<0.01 ; * * \star x p<\right.$ $0.001 ; * * \star * p<0.0001)$ vs baseline for PROCLAIM week 24 or vs $\geq$ LLN for ENDORSE integrated analysis ALC categories. (A) Naive $\mathrm{CD}^{+} \mathrm{T}$ cells $\left(\mathrm{CD}^{+} / \mathrm{CD}^{+} 5 \mathrm{RA}^{+} / \mathrm{CCR}^{+}\right)$, effector $\mathrm{CD} 4^{+}$ T cells $\left(\mathrm{CD}^{+} / \mathrm{CD}^{+} 5 \mathrm{RA}{ }^{+} / \mathrm{CCR}^{-}\right)$, central memory $\mathrm{CD}^{+}{ }^{\mathrm{T}}$ cells (CD4 ${ }^{+} / \mathrm{CD}^{-}$45A ${ }^{-}$/ $\left(\mathrm{CR} 7^{+}\right.$), effector memory $\mathrm{CD} 4^{+} \mathrm{T}$ cells $\left(\mathrm{CD}^{+} / \mathrm{CD}^{-} 5 \mathrm{RA}^{-} / \mathrm{CCR}^{-}\right)$, and activated $\mathrm{CD}^{+} \mathrm{T}$ cells $\left(\mathrm{CD}^{+} / \mathrm{CD}^{+} 8^{+} / \mathrm{HLA}^{-} \mathrm{DR}^{+}\right.$). (B) Naive $\mathrm{CD}^{+} \mathrm{T}$ cells $\left(\mathrm{CD}^{+} / \mathrm{CD}^{2} 5 \mathrm{RA}^{+} /\right.$ (CR7 $\left.{ }^{+}\right)$, effector $\mathrm{CD}^{+} \mathrm{T}$ cells $\left(\mathrm{CD}^{+} /\right.$ $\mathrm{CD}^{2} 5 \mathrm{RA}^{+} /\left(\mathrm{CCR}^{-}\right)$, central memory $\mathrm{CD}^{+}{ }^{\mathrm{T}}$ cells $\left(\mathrm{CD}^{+} / \mathrm{CD}^{+} 5 \mathrm{RA}^{-} / \mathrm{CCR}^{+}\right)$, effector memory $\mathrm{CD}^{+} \mathrm{T}$ cells $\left(\mathrm{CD}^{+} /\right.$ $\left.\mathrm{CD}^{2} 5 \mathrm{RA}^{-} / \mathrm{CCR}^{-}\right)$, and activated $\mathrm{CD} 8^{+}$ T cells $\left(\mathrm{CD}^{+} / \mathrm{CD}^{2} 8^{+} / \mathrm{HLA}^{-} \mathrm{DR}^{+}\right)$. (C) Naive regulatory $\mathrm{T}$ cells $\left(\mathrm{CD}^{+} / \mathrm{CD}^{2} 5^{+} /\right.$ $\mathrm{CD} 127^{\text {low } /} / \mathrm{CD}^{2} 5 \mathrm{RO}^{-}$), effector regulatory $\mathrm{T}$ cells $\left(\mathrm{CD} 4^{+} / \mathrm{CD} 25^{+} / \mathrm{CD} 127^{\mathrm{low}} /\right.$ $\left.\mathrm{CD}^{2} 5 \mathrm{RO}^{+}\right)$, Th1 phenotype $\left(\mathrm{CD}^{+} /\right.$ $\left.\mathrm{CXCR}^{+} / \mathrm{CCR}^{-}\right)$, Th2-enriched phenotype (CD4 $\left.{ }^{+} / \mathrm{CXCR3}^{-} / \mathrm{CCR}^{-}\right)$, and Th17 phenotype $\mathrm{Th}=\mathrm{T}$ helper . 
Figure 5 Proportions of immune cell subsets during early (PROCLAIM) and long-term (ENDORSE integrated analysis) dimethyl fumarate (DMF) treatment

A

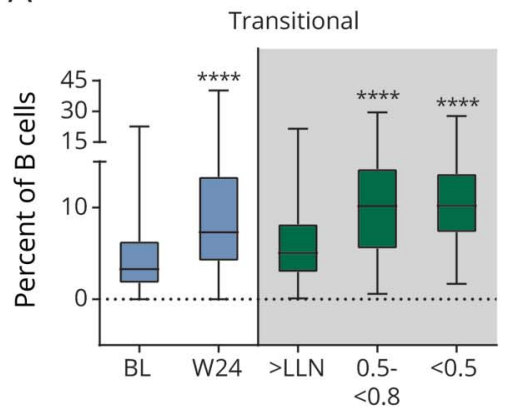

IgD- memory (class switched)

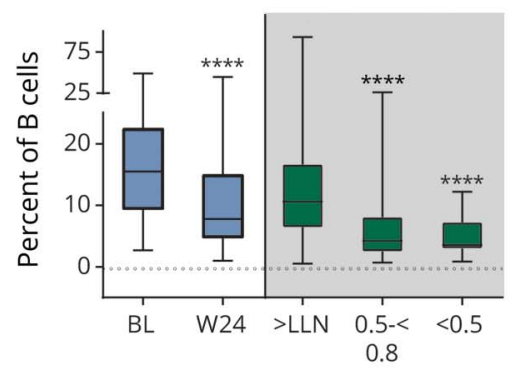

B

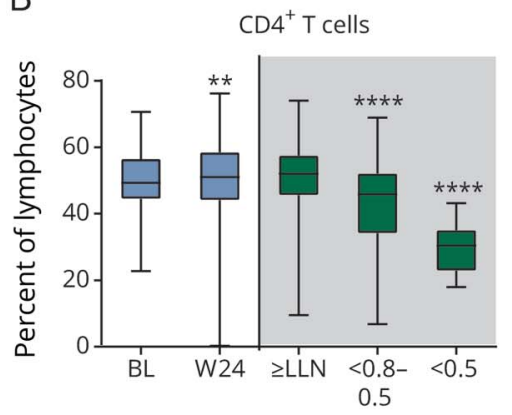

CD56 ${ }^{\text {bright }}$ NK cells

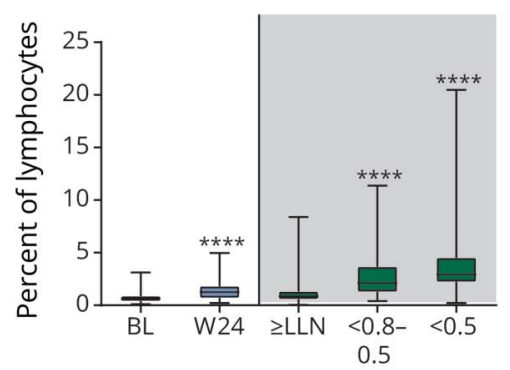

Naive

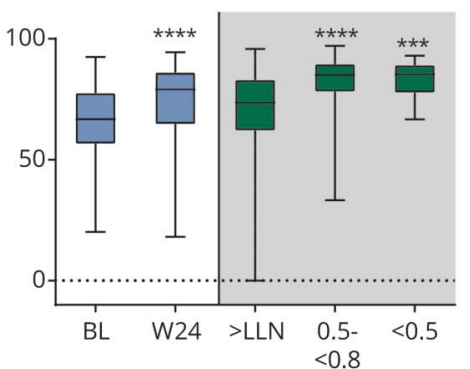

Plasmablasts

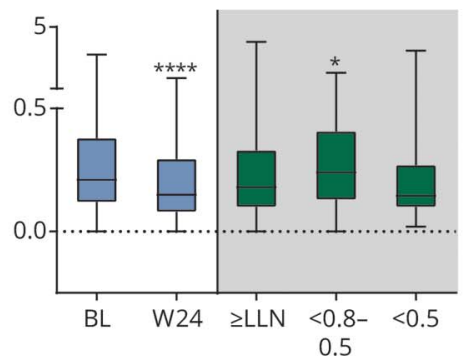

$\mathrm{CD}^{+} \mathrm{T}$ cells

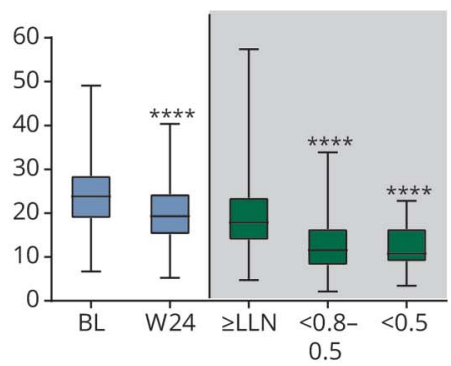

CD56 $^{\text {dim }}$ NK cells

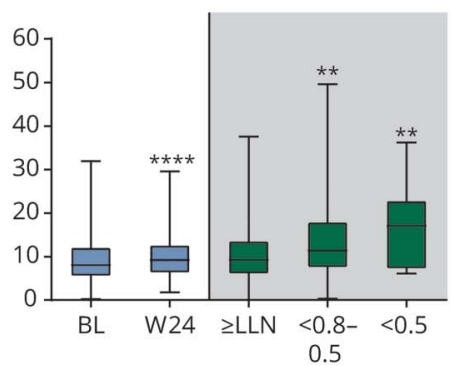

IgD ${ }^{+}$memory (nonclass switched)

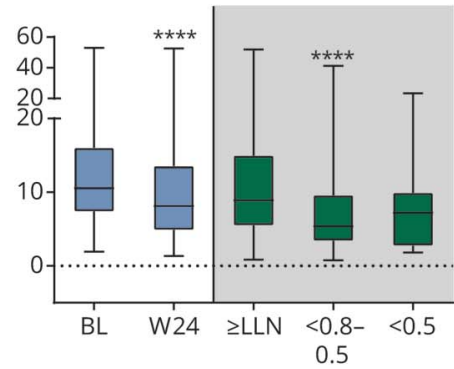

CD138+ plasma cells

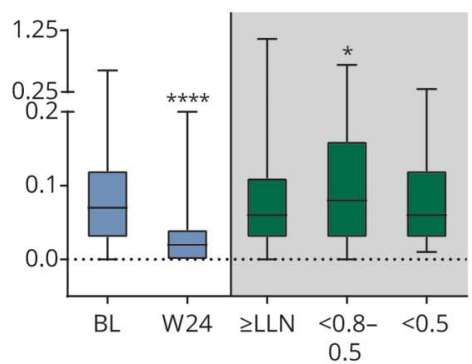

$B$ cells

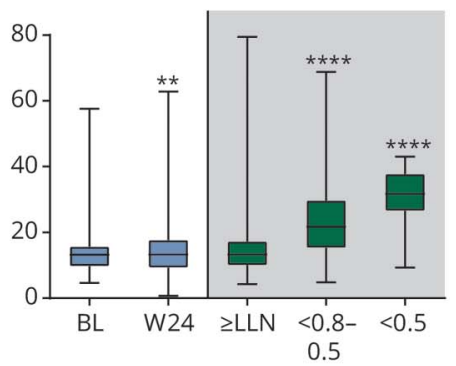

Study visit

ALC category

$\square$ PROCLAIM

ENDORSE

PROCLAIM ( $n=163$ ) and the BG00012 Monotherapy Safety and Efficacy Extension Study in Multiple Sclerosis (ENDORSE) integrated analysis ( $\mathrm{n}=694)$ are shown. For each box plot, the top and bottom box edges correspond to the first and third quartiles. The black line inside the box represents the median. The top and bottom whisker lines mark the maximum and minimum values of the dataset, respectively. For PROCLAIM (shaded white), the box plots represent the longitudinal trajectory in lymphocyte subsets during early treatment (from baseline [BL] to week 24 [W24]). For the ENDORSE integrated analysis (shaded gray), the box plots represent the cross-sectional observations in lymphocyte subsets in patients who had been exposed to DMF for $\sim 5$ years, stratified by absolute lymphocyte count (ALC) category. For the ENDORSE integrated analysis, data were stratified by ALC categories (ALC always $\geq 0.91 \times 10^{9} / L$ [ $\geq$ lower limit of normal (LLN)]; ALC $<0.8-0.5 \times 10^{9} / \mathrm{L}$ for $\geq 6$ months [moderate, prolonged lymphopenia, $<0.8-0.5$ ]; ALC $<0.5 \times 10^{9} / \mathrm{L}$ for $\geq 6 \mathrm{months}$ [severe, prolonged lymphopenia, $<0.5]$ ). Patients were categorized as having moderate to severe, prolonged lymphopenia if they met these criteria at any time during the study. $p$ values were calculated using Wilcoxon signed-rank test, compared the absolute change in relative proportion of lymphocyte subsets at week 24 with baseline for PROCLAIM, were calculated using a pairwise 2-sample Wilcoxon test, and compared the absolute change in relative proportion of lymphocyte subsets for moderate and severe, prolonged lymphopenia compared with ALCs $\geq$ LLN for the ENDORSE integrated analysis. Significant $p$ values are marked with asterisks $\left({ }^{*} p<0.05 ; * \star p<0.01 ; * \star \star p<0.001\right.$;

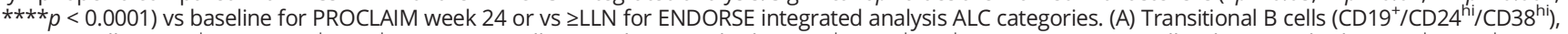

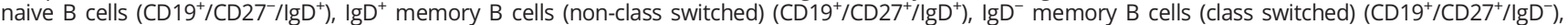
plasmablasts $\left(\mathrm{CD} 19^{+} / \mathrm{CD} 27^{++} / \mathrm{CD} 38^{++}\right)$, and CD138 ${ }^{+}$plasma cells $\left(\mathrm{CD} 19^{+} / \mathrm{CD} 27^{++} / \mathrm{CD} 38^{++} / \mathrm{CD} 138^{+}\right)$. (B) CD4 ${ }^{+} \mathrm{T}_{\text {cells }}\left(\mathrm{CD} 3^{+} / \mathrm{CD} 4^{+}\right), \mathrm{CD}^{+} \mathrm{T}_{\text {cells }}\left(\mathrm{CD} 3^{+} / \mathrm{CD} 8^{+}\right), \mathrm{B}$ cells

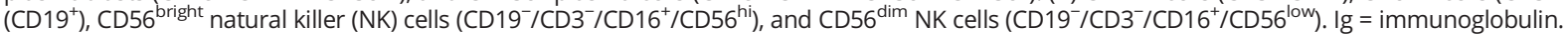


Table 2 Incidence of infection, malignancy, and herpes zoster by absolute lymphocyte count (ALC) category and by CD4 ${ }^{+}$ and $C D 8^{+} \mathrm{T}$-cell subset count in the long-term ENDORSE integrated analysis

\begin{tabular}{|c|c|c|c|c|c|c|c|c|c|}
\hline & \multicolumn{4}{|l|}{ ALC category } & \multicolumn{2}{|l|}{$\mathrm{CD}^{+}$} & \multicolumn{2}{|l|}{$\mathrm{CD}^{+}$} & \multirow[b]{2}{*}{ Total } \\
\hline & $\begin{array}{l}<0.5 \times 10^{9} / \mathrm{L} \\
\text { for } \geq 6 \mathrm{mo}\end{array}$ & $\begin{array}{l}\geq 0.5 \text { to }<0.8 \times 10^{9} / \mathrm{L} \\
\text { for } \geq 6 \mathrm{mo}^{\mathrm{a}}\end{array}$ & $\begin{array}{l}<\text { LLN at } \\
\text { any time }{ }^{b}\end{array}$ & $\begin{array}{l}\text { Always } \\
\geq \text { LLN }\end{array}$ & $\begin{array}{l}\leq 0.2 \times \\
10^{9} / L\end{array}$ & $\begin{array}{l}>0.2 \times \\
10^{9} / L\end{array}$ & $\begin{array}{l}\leq 0.1 \times \\
10^{9} / L\end{array}$ & $\begin{array}{l}>0.1 \times \\
10^{9} / \mathrm{L}\end{array}$ & \\
\hline Patients, $\mathbf{n}$ & 53 & 232 & 678 & 1,489 & 61 & 748 & 189 & 620 & 809 \\
\hline Patient-years & 301 & 1,406 & 3,310 & 5,133 & 412 & 5,235 & 1,320 & 4,327 & 5,647 \\
\hline $\begin{array}{l}\text { Serious infection/ } \\
\text { patient-years }\end{array}$ & 0.02 & $<0.01$ & 0.01 & 0.01 & 0.01 & $<0.01$ & $<0.01$ & $<0.01$ & $<0.01$ \\
\hline $\begin{array}{l}\text { Opportunistic infection/ } \\
\text { patient-years }\end{array}$ & $<0.01$ & 0 & 0 & 0 & 0 & 0 & 0 & 0 & 0 \\
\hline $\begin{array}{l}\text { Malignancy/patient- } \\
\text { years }\end{array}$ & $<0.01$ & $<0.01$ & $<0.01$ & $<0.01$ & $<0.01$ & $<0.01$ & $<0.01$ & $<0.01$ & $<0.01$ \\
\hline $\begin{array}{l}\text { Herpes zoster/patient- } \\
\text { years }^{c}\end{array}$ & 0.01 & 0.01 & $<0.01$ & $<0.01$ & 0.02 & $<0.01$ & 0.02 & $<0.01$ & $<0.01$ \\
\hline
\end{tabular}

Abbreviations: ENDORSE = BG00012 Monotherapy Safety and Efficacy Extension Study in Multiple Sclerosis; LLN = lower limit of normal.

Incidence was calculated as the number of patients with certain adverse events divided by the total patient-years of follow-up. Patient-year = sum (last date in study - date of first exposure to delayed-release dimethyl fumarate + 1)/365.25.

a Excludes $<0.5 \times 10^{9} / \mathrm{L}$ for $\geq 6$ months.

${ }^{\mathrm{b}}$ Excludes $<0.8 \times 10^{9} / \mathrm{L}$ for $\geq 6$ months.

c No herpes zoster case qualified as an opportunistic infection.

The safety profile AEs (in 79\% of patients) and SAEs (in 4\% of patients) in PROCLAIM were consistent with the known safety profile of DMF. ${ }^{2,3,6}$ As of the 6-month follow-up, no opportunistic infections or serious infections have been reported during the study, though duration of exposure is limited.

\section{Lymphocyte discontinuation and reconstitution in the integrated analysis of ENDORSE}

Limited data are available to assess the reconstitution of lymphocytes after discontinuation of DMF. In an analysis of patients with $\geq 1 \mathrm{ALC}<0.8 \times 10^{9} / \mathrm{L}$ while on treatment with DMF (excluding patients with $<0.5 \times 10^{9} / \mathrm{L}$ for $\geq 6$ months), and $\geq 1$ ALC after DMF discontinuation $(\mathrm{n}=207)$, the majority of patients achieved an ALC of $\geq 0.8 \times 10^{9} / \mathrm{L}(82 \%)$ or $0.91 \times 10^{9} / \mathrm{L}(\mathrm{LLN} ; 68 \%)$ after DMF discontinuation; $63 \%$ and $53 \%$ of these patients reached those levels within 4-5 weeks (table 3). However, it was not possible to assess lymphocyte subset reconstitution for these patients, as data were limited.

Patients with severe, prolonged lymphopenia were analyzed separately due to the prolonged duration of lymphopenia while on treatment with DMF. Once these 49 patients had an ALC $<0.5 \times 10^{9} / \mathrm{L}$ for 6 months, they continued to receive treatment with DMF for a mean of 2.9 years before discontinuing therapy. This duration of lymphopenia was prolonged relative to current clinical practice due to amendments to prescribing guidelines. However, of these patients, $15 \mathrm{had}$ $\geq 3$ separate measurements of T-cell subsets recorded after discontinuation of DMF. Of the 15 patients with data available, select individual patient plots to describe the reconstitution of T-cell subsets in the context of ALC reconstitution are presented (figure e-2; doi.org/10.5061/ dryad.d065rr9). The high correlation observed between ALC and $\mathrm{T}$-cell subsets while on treatment may suggest a persistent effect following discontinuation; however, due to the spontaneity of collection and small patient numbers, it was not feasible to do a correlative analysis and this could not be confirmed.

\section{Discussion}

These findings from a total of 2,633 DMF-treated patients with RRMS in 2 clinical trials, some of whom had long-term treatment with DMF, continue to reflect the well-described pattern of lymphocyte count decline followed by stabilization and corroborate previous smaller studies reporting reductions in circulating lymphocyte subsets corresponding with ALC decline early in the course of treatment, ${ }^{1,7-9,15,16}$ further demonstrating a maintenance of these changes during longterm treatment. These data indicate that subset changes are closely aligned with the dynamics of overall ALC change, and specifically demonstrate a strong correlation between ALC levels and T-cell subset counts, which underscores the clinical utility and sufficiency of monitoring ALC levels by a routine CBC during DMF treatment.

$\mathrm{CD}^{+} \mathrm{T}$ cells demonstrated a greater relative decline compared to $\mathrm{CD} 4^{+} \mathrm{T}$ cells, in line with previous observations. ${ }^{17} \mathrm{It}$ has been well-described that $\mathrm{CD}^{+} \mathrm{T}$ lymphocytes are critical for cell-mediated antiviral immunity. ${ }^{7,18}$ However, with the exception of rare PML in the setting of moderate to severe, prolonged lymphopenia observed in clinical trial and realworld settings, the data from this large population of clinical 
Table 3 Demographic and clinical characteristics for patients in the ENDORSE integrated analysis who discontinued dimethyl fumarate (DMF), stratified by lymphocyte levels

\begin{tabular}{|c|c|c|}
\hline & $\begin{array}{l}\text { ALC }<0.8 \times 10^{9} / L \text { any time, } \\
n=207\end{array}$ & $\begin{array}{l}\text { ALC }<0.5 \times 10^{9} / \mathrm{L} \text { for } \geq 6 \mathrm{mo}, \\
n=49\end{array}$ \\
\hline \multicolumn{3}{|l|}{ Baseline characteristics } \\
\hline Age, y, mean (SD) & $38(9)$ & $44(8)$ \\
\hline Baseline ALC $\times 10^{9} / L$, mean (SD) & $1.70(0.47)$ & $1.64(0.41)$ \\
\hline \multicolumn{3}{|l|}{ On DMF } \\
\hline $\begin{array}{l}\text { Baseline to last ALC on or before DMF discontinuation or } \\
\text { interruption (mean percent change in ALC) }\end{array}$ & $-40 \%$ & $-70 \%$ \\
\hline \multicolumn{3}{|l|}{ Duration of DMF exposure, mo } \\
\hline Mean (SD) & $45(27)$ & $64(21)$ \\
\hline Median (min, max) & $40(3,117)$ & $63(16,97)$ \\
\hline ALC on or before DMF discontinuation, $\times 10^{9} / \mathrm{L}$, median $(\min , \max )$ & $0.85(0.29,3.08)$ & $0.43(0.26,0.91)$ \\
\hline Rate of serious infection/patient-years & 0.017 & 0.008 \\
\hline \multicolumn{3}{|l|}{ After discontinuation of DMF } \\
\hline Duration of follow-up post-DMF, mo, mean (SD) & $2.0(3.3)$ & $8.1(6.2)$ \\
\hline Last ALC recorded during follow-up post-DMF, $\times 10^{9} / \mathrm{L}$, mean (SD) & $1.10(0.39)$ & $0.71(0.20)$ \\
\hline Relapses during recovery period, mean (SD) & $0.1(0.3)$ & $0.3(0.7)$ \\
\hline Patients with no relapse during recovery period, $\mathrm{n}(\%)$ & $198(96)$ & $39(80)$ \\
\hline \multicolumn{3}{|l|}{ Maximum ALC recorded during follow-up post DMF, $\times 10^{9} / L$, mean (SD) } \\
\hline$\geq 0.8 \times 10^{9} / \mathrm{L}, \mathrm{n}(\%)$ & $170(82)$ & 19 (39) \\
\hline Time to recorded ALC $\geq 0.8 \times 10^{9} / \mathrm{L}$, wk, median ${ }^{b}$ & 3.57 & 35.4 \\
\hline Minimum ALC recorded on DMF: $<0.5 \times 10^{9} / \mathrm{L}, \mathrm{n} / \mathrm{N}(\%)$ & $40 / 170(19)$ & $19 / 19(100)$ \\
\hline Minimum ALC recorded on DMF: $0.5-<0.8 \times 10^{9} / L, n / N(\%)$ & $130 / 170(63)$ & 0 \\
\hline$\geq 0.91 \times 10^{9} / \mathrm{L}$ & $141(68)$ & $13(27)$ \\
\hline Time to recorded ALC $\geq 0.91 \times 10^{9} / \mathrm{L}$, wk, median ${ }^{b}$ & 4.57 & N/A \\
\hline Minimum ALC recorded on DMF: $<0.5 \times 10^{9} / \mathrm{L}, \mathrm{n} / \mathrm{N}(\%)$ & $31 / 141(15)$ & $13 / 13(100)$ \\
\hline Minimum ALC recorded on DMF: $0.5-<0.8 \times 10^{9} / \mathrm{L}, \mathrm{n} / \mathrm{N}(\%)$ & $110 / 141(53)$ & 0 \\
\hline Serious infection/patient-years during untreated period ${ }^{\mathrm{C}}$ & 0.089 & 0.057 \\
\hline
\end{tabular}

Abbreviations: ALC = absolute lymphocyte count; ENDORSE = BG00012 Monotherapy Safety and Efficacy Extension Study in Multiple Sclerosis.

Values are mean (SD) unless otherwise indicated. Patient-year = sum (last date in study - date of first exposure to DMF +1 )/365.25. Incidence was calculated as the number of patients with certain adverse events divided by the total patient-years of follow-up. The population was restricted to $\geq 1$ ALC record post-DMF discontinuation (deferring to only 1 ALC record if 2 or more ALCs recorded on the same day). Of the patients with ALC $<0.5 \times 10^{9} / L$ for $\geq 6$ months, 1 received interferon- $\beta-1 a, 1$ received interferon- $\beta-1 b, 1$ received teriflunomide, and 1 received fampridine.

a Excludes $<0.5 \times 10^{9} / \mathrm{L}$ for $\geq 6$ months.

${ }^{\mathrm{b}}$ Estimates for the median (50\%) of time ALC $<$ values noted were obtained from a Kaplan-Meier curve.

${ }^{c}$ During the recovery period, $29 / 207(14 \%)$ of patients with ALC $<0.8 \times 10^{9} / L$ received an alternate DMF. Of those, 11 received interferon- $\beta-1$ a, 4 received alemtuzumab, 4 received teriflunomide, 3 received fingolimod, 2 received dimethyl fumarate, 2 received natalizumab, 2 received rituximab, and 1 received glatiramer acetate.

trial patients treated for many years with DMF did not demonstrate any increased incidence of serious infection or opportunistic infection, regardless of ALC or T-cell subset levels.

These datasets also confirm that DMF shifts the immune repertoire of circulating $\mathrm{T}$ and $\mathrm{B}$ cells, resulting in a relative expansion of naive and immunoregulatory cells. ${ }^{1,7-9,15,19}$ The relative proportion of the total regulatory $\mathrm{T}$ cells among the $\mathrm{CD}^{+}{ }^{+} \mathrm{T}$-cell population was stable during DMF treatment, suggesting that an appropriate T-reg:T-effector ratio would be maintained to support immune tolerance mechanisms. Interestingly, there also was a relative increase in the activation status of $\mathrm{CD}^{+}$and $\mathrm{CD} 4^{+} \mathrm{T}$ cells. The increased activation 
status of $\mathrm{CD}^{+}$and $\mathrm{CD}^{+} \mathrm{T}$ cells may reflect increased homeostatic expansion. ${ }^{20-23}$ This increase in an "activated" phenotype is likely indicative of active immune reconstitution in response to the decline in $\mathrm{T}$ cells in patients treated with DMF. Notably, the most significant decline during exposure to $\mathrm{DMF}$ appears to be on $\mathrm{CD} 8^{+}$central memory, $\mathrm{CD} 8^{+}$and $\mathrm{CD}^{+}$effector memory $\mathrm{T}$ cells, and class-switched memory $B$ cells, which may explain why no increased incidence of infection was observed in DMF-treated patients. This DMFmediated shift to an anti-inflammatory state may lead to improvements in disease activity, similar to what has been noted for the B-cell compartment. ${ }^{19}$ These relative changes are observed regardless of absolute cell counts or ALC category. Because clinical data suggest the presence of lymphopenia is not required for MS relapse-reduction efficacy, the level of ALC reduction or prolonged lymphopenia is not likely to be the primary mechanistic driver of DMF; the contributory effects of cumulative subset-specific changes must still be further explored. While some research has been done to propose specific mechanisms responsible for immune cell loss, $7,8,15,24,25$ there are likely multiple mechanisms of action for DMF, as well as patient-intrinsic factors, that are currently not well-understood and lead to the heterogeneous effect of DMF on the immune system.

Despite challenges to collecting data in patients after discontinuation from study drug as the majority of patients discontinuing study drug simultaneously discontinue the clinical trial, this dataset provides the first opportunity to describe postDMF ALC dynamics in a population of $>200$ patients. Following DMF treatment discontinuation in patients with moderate lymphopenia while on treatment, lymphocyte counts generally increased over time. Most patients achieved an ALC $>0.8 \times 10^{9} / \mathrm{L}$ approximately 1 month after discontinuation. By contrast, the time to reconstitution was longer for patients with severe, prolonged lymphopenia, likely due to the longer time that the patients had severe, prolonged lymphopenia while on treatment. The increase in the proportion of $\mathrm{CD}^{+}{ }^{+}$and $\mathrm{CD} 8^{+}$effector memory, $\mathrm{CD} 8^{+}$effector, effector regulatory $\mathrm{T}$, and $\mathrm{Th} 1 \mathrm{~T}$ cells only among patients with severe, prolonged lymphopenia, together with the increase in activated T, transitional B, and CD $56^{\text {bright }} \mathrm{NK}$ cells, likely reflect the active dynamics of attempted immune system reconstitution during a chronically lymphopenic state.

The current analysis was subject to inherent limitations associated with integrating data from trials that may have important differences in design, patient population, data extraction procedures, and statistical methodology. In addition, patients enrolled into clinical trials may not fully reflect patients treated in clinical practice, thus continued use of DMF in a real-world population will further describe the benefit-risk profile of DMF. Despite these limitations, amalgamating patient data for this integrated analysis provided an increased sample size and provided consistent observed outcomes.
Taken together, these data provide critical context for the clinical implications of T-cell subset changes in DMF-treated patients and taken together with the strong correlation between ALC and T-cell subsets, continue to support that additional monitoring of $\mathrm{T}$-cell subsets is not required or necessary for safety surveillance in routine clinical practice for patients treated with DMF. The results of these analyses reinforce initial observations documenting the immunomodulatory effects of DMF on lymphocyte subsets. Most importantly, the safety profile of DMF in these studies is consistent with its known effects in adult patients with relapsing forms of MS, and continues to support the positive benefit-risk profile observed in both clinical trial and realworld patients treated with DMF.

\section{Acknowledgment}

The authors thank the study participants. Biogen provided funding for medical writing support in the development of this article; Kristen DeYoung from Excel Scientific Solutions copyedited and styled the manuscript per journal requirements. Biogen reviewed and provided feedback on the article to the authors. The authors had full editorial control of the article, and provided their final approval of all content.

\section{Study funding}

This study was funded by Biogen.

\section{Disclosure}

D. Mehta is an employee of and holds stock/stock options in Biogen. C. Miller is an employee of and holds stock/stock options in Biogen. D. Arnold has received consulting fees and/or grants from Acorda, Adelphi, Alkermes, Biogen, Celgene, Genentech, Genzyme, Hoffman-La Roche, Immune Tolerance Network, Immunotec, International Progressive MS Alliance, MedDay, MS Society of Canada, Novartis, Pfizer, Receptos, Roche, and Sanofi-Aventis, and has equity interest in NeuroRx Research. E. Bame is an employee of and holds stock/stock options in Biogen. A. Bar-Or has participated as a speaker in meetings sponsored by and received consulting fees and/or grant support from Atara, Biogen, Celgene/Receptos, Genentech/Roche, GlaxoSmithKline, MedImmune, Merck/ EMD Serono, Novartis, and Sanofi-Genzyme. R. Gold has received honoraria from Bayer HealthCare, Biogen, Merck Serono, Novartis, and Teva Neuroscience; research support from Bayer HealthCare, Biogen, Merck Serono, Novartis, and Teva Neuroscience; and compensation from Sage for serving as editor of Therapeutic Advances in Neurologic Disorders. J. Hanna is an employee of and holds stock/stock options in Biogen. L. Kappos' institution (University Hospital Basel) received in the last 3 years and used exclusively for research support at the department: steering committee, advisory board, and consulting fees from Actelion, Alkermes, Almirall, Bayer HealthCare, Biogen, Celgene/Receptos, df-mp, Excemed, GeNeuro SA, Genzyme, Japan Tobacco, Merck, Minoryx, Mitsubishi, Novartis, Roche, Sanofi-Aventis, Santhera, Teva, and Vianex, and royalties for Neurostatus-UHB products. The research of the MS Center in Basel has been supported by grants from Bayer HealthCare, 
Biogen, the European Union, Novartis, Roche Research Foundations, the Swiss MS Society, and the Swiss National Research Foundation. S. Liu is an employee of and holds stock/stock options in Biogen. A. Matta is an employee of and holds stock/ stock options in Biogen. J. Phillips has received consulting fees from Acorda, Biogen, Genzyme, EMD Serono, and SanofiAventis. D. Robertson has been a consultant for Biogen, EMD Serono, Genentech, Genzyme, Novartis, and Teva; has received honoraria or speaker fees from Acorda, Biogen, EMD Serono, Genentech, Genzyme, Mallinckrodt, Novartis, and Teva; and has received research grant support from Actelion, Biogen, EMD Serono, Genentech, Genzyme, Mallinckrodt, MedImmune, Novartis, Parexel, Sun, and TG Therapeutics. C. von Hehn is an employee of and holds stock/stock options in Biogen. J. Campbell is an employee of and holds stock/stock options in Envision Pharma Group. K. Spach is an employee of and holds stock/stock options in Envision Pharma Group. L. Yang is an employee of and holds stock/stock options in Biogen. R. Fox has received consulting fees from Biogen, MedDay, Novartis, Questcor, Teva, and Xenoport; has been a part of advisory boards for Biogen and Novartis; and has received research grant funding from Novartis. Go to Neurology.org/N for full disclosures.

\section{Publication history}

Received by Neurology August 2, 2018. Accepted in final form December 4, 2018 .

Appendix Authors

\begin{tabular}{|c|c|c|}
\hline Name & Location & Contributions \\
\hline $\begin{array}{l}\text { Devangi } \\
\text { Mehta }\end{array}$ & $\begin{array}{l}\text { Biogen, } \\
\text { Cambridge, MA }\end{array}$ & $\begin{array}{l}\text { Participated in the } \\
\text { study design, } \\
\text { interpretation of } \\
\text { study results and in } \\
\text { the drafting, critical } \\
\text { revision, and } \\
\text { approval of the final } \\
\text { manuscript }\end{array}$ \\
\hline $\begin{array}{l}\text { Catherine } \\
\text { Miller }\end{array}$ & $\begin{array}{l}\text { Biogen, } \\
\text { Cambridge, MA }\end{array}$ & $\begin{array}{l}\text { Participated in the } \\
\text { study design, } \\
\text { interpretation of } \\
\text { study results and in } \\
\text { the drafting, critical } \\
\text { revision, and } \\
\text { approval of the final } \\
\text { manuscript }\end{array}$ \\
\hline
\end{tabular}

\begin{tabular}{|c|c|c|c|}
\hline $\begin{array}{l}\text { Douglas L. } \\
\text { Arnold }\end{array}$ & $\begin{array}{l}\text { NeuroRx and } \\
\text { McGill University, } \\
\text { Montreal, Canada }\end{array}$ & Investigator & $\begin{array}{l}\text { Participated in the } \\
\text { interpretation of } \\
\text { study results and in } \\
\text { the drafting, critical } \\
\text { revision, and } \\
\text { approval of the final } \\
\text { version of the } \\
\text { manuscript }\end{array}$ \\
\hline
\end{tabular}

\begin{tabular}{ll}
\hline Eris Bame $\quad \begin{array}{l}\text { Biogen, } \\
\text { Cambridge, MA }\end{array}$ & Participated in the \\
& interpretation of \\
& study results and in \\
& the drafting, critical \\
& revision, and \\
& approval of the final \\
& version of the \\
& manuscript
\end{tabular}

Appendix (continued)

\begin{tabular}{|c|c|c|c|}
\hline Name & Location & Role & Contributions \\
\hline $\begin{array}{l}\text { Amit Bar- } \\
\text { Or }\end{array}$ & $\begin{array}{l}\text { University of } \\
\text { Pennsylvania, } \\
\text { Philadelphia }\end{array}$ & Investigator & $\begin{array}{l}\text { Participated in the } \\
\text { interpretation of study } \\
\text { results and in the } \\
\text { drafting, critical } \\
\text { revision, and approval } \\
\text { of the final version of } \\
\text { the manuscript }\end{array}$ \\
\hline Ralf Gold & $\begin{array}{l}\text { Ruhr University, } \\
\text { Bochum, } \\
\text { Germany }\end{array}$ & Investigator & $\begin{array}{l}\text { Participated in the } \\
\text { interpretation of study } \\
\text { results and in the } \\
\text { drafting, critical } \\
\text { revision, and approval } \\
\text { of the final version of } \\
\text { the manuscript }\end{array}$ \\
\hline $\begin{array}{l}\text { Jerome } \\
\text { Hanna }\end{array}$ & $\begin{array}{l}\text { Biogen, } \\
\text { Cambridge, MA }\end{array}$ & & $\begin{array}{l}\text { Participated in the } \\
\text { interpretation of } \\
\text { study results and in } \\
\text { the drafting, critical } \\
\text { revision, and } \\
\text { approval of the final } \\
\text { version of the } \\
\text { manuscript }\end{array}$ \\
\hline
\end{tabular}

\begin{tabular}{|c|c|c|c|}
\hline $\begin{array}{l}\text { Ludwig } \\
\text { Kappos }\end{array}$ & $\begin{array}{l}\text { University } \\
\text { Hospital Basel, } \\
\text { Switzerland }\end{array}$ & Investigator & $\begin{array}{l}\text { Participated in the } \\
\text { interpretation of } \\
\text { study results and in } \\
\text { the drafting, critical } \\
\text { revision, and } \\
\text { approval of the final } \\
\text { version of the } \\
\text { manuscript }\end{array}$ \\
\hline $\begin{array}{l}\text { Shifang } \\
\text { Liu }\end{array}$ & $\begin{array}{l}\text { Biogen, } \\
\text { Cambridge, MA }\end{array}$ & & $\begin{array}{l}\text { Conducted the } \\
\text { statistical analysis } \\
\text { and contributed to } \\
\text { the drafting, critical } \\
\text { revision, and } \\
\text { approval of the final } \\
\text { version of the } \\
\text { manuscript }\end{array}$ \\
\hline
\end{tabular}

\begin{tabular}{lll}
\hline Andre & Biogen, & Participated in the \\
Matta & Cambridge, MA & interpretation of study \\
& results and in the \\
& drafting, critical \\
& revision, and approval \\
& of the final version of \\
& the manuscript
\end{tabular}

\begin{tabular}{|c|c|c|c|}
\hline $\begin{array}{l}\text { J. } \\
\text { Theodore } \\
\text { Phillips }\end{array}$ & $\begin{array}{l}\text { University of New } \\
\text { Mexico Health } \\
\text { Sciences Center, } \\
\text { Albuquerque }\end{array}$ & Investigator & $\begin{array}{l}\text { Participated in the } \\
\text { interpretation of study } \\
\text { results and in the } \\
\text { drafting, critical } \\
\text { revision, and approval } \\
\text { of the final version of } \\
\text { the manuscript }\end{array}$ \\
\hline
\end{tabular}

\begin{tabular}{|c|c|c|c|}
\hline $\begin{array}{l}\text { Derrick } \\
\text { Robertson }\end{array}$ & $\begin{array}{l}\text { University of } \\
\text { South Florida, } \\
\text { Tampa }\end{array}$ & Investigator & $\begin{array}{l}\text { Participated in the } \\
\text { interpretation of study } \\
\text { results and in the } \\
\text { drafting, critical } \\
\text { revision, and approval } \\
\text { of the final version of } \\
\text { the manuscript }\end{array}$ \\
\hline
\end{tabular}

\begin{tabular}{lll}
\hline Christian & Biogen, & Participated in the \\
von Hehn & Cambridge, MA & interpretation of \\
& study results and in \\
& the drafting, critical \\
& revision, and \\
& approval of the final \\
& version of the \\
& manuscript
\end{tabular}

Continued 
Appendix (continued)

\begin{tabular}{|c|c|c|c|}
\hline Name & Location & Role & Contributions \\
\hline Lili Yang & $\begin{array}{l}\text { Biogen, } \\
\text { Cambridge, MA }\end{array}$ & Statistician & $\begin{array}{l}\text { Conducted the } \\
\text { statistical analysis } \\
\text { and contributed to } \\
\text { the drafting, critical } \\
\text { revision, and } \\
\text { approval of the final } \\
\text { version of the } \\
\text { manuscript }\end{array}$ \\
\hline $\begin{array}{l}\text { Robert J. } \\
\text { Fox }\end{array}$ & $\begin{array}{l}\text { Cleveland Clinic, } \\
\mathrm{OH}\end{array}$ & Investigator & $\begin{array}{l}\text { Participated in the } \\
\text { interpretation of } \\
\text { study results and in } \\
\text { the drafting, critical } \\
\text { revision, and } \\
\text { approval of the final } \\
\text { version of the } \\
\text { manuscript }\end{array}$ \\
\hline
\end{tabular}

\section{References}

1. Fox RJ, Chan A, Gold R, et al. Characterizing absolute lymphocyte count profiles in dimethyl fumarate-treated patients with MS: patient management considerations. Neurol Clin Pract 2016;6:220-229.

2. Fox RJ, Miller DH, Phillips JT, et al. Placebo-controlled phase 3 study of oral BG-12 or glatiramer in multiple sclerosis. N Engl J Med 2012;367:1087-1097.

3. Gold R, Kappos L, Arnold DL, et al. Placebo-controlled phase 3 study of oral BG-12 for relapsing multiple sclerosis. N Engl J Med 2012;367:1098-1107.

4. Kappos L, Gold R, Miller DH, et al. Efficacy and safety of oral fumarate in patients with relapsing-remitting multiple sclerosis: a multicentre, randomised, double-blind, placebo-controlled phase IIb study. Lancet 2008;372:1463-1472.

5. Rosenkranz T, Novas M, Terborg C. PML in a patient with lymphocytopenia treated with dimethyl fumarate. N Engl J Med 2015;372:1476-1478.

6. Food and Drug Administration. Tecfidera [prescribing information]. Cambridge, MA: Biogen; 2017.

7. Longbrake EE, Ramsbottom MJ, Cantoni C, Ghezzi L, Cross AH, Piccio L. Dimethyl fumarate selectively reduces memory $\mathrm{T}$ cells in multiple sclerosis patients. Mult Scler 2016;22:1061-1070.

8. Fleischer V, Friedrich M, Rezk A, et al. Treatment response to dimethyl fumarate is characterized by disproportionate CD8+ T cell reduction in MS. Mult Scler 2018;24:632-641.

9. Ghadiri M, Rezk A, Li R, et al. Dimethyl fumarate-induced lymphopenia in MS due to differential T-cell subset apoptosis. Neurol Neuroimmunol Neuroinflamm 2017;4:e340.

10. Polman $\mathrm{CH}$, Reingold SC, Banwell B, et al. Diagnostic criteria for multiple sclerosis: 2010 revisions to the McDonald criteria. Ann Neurol 2011;69:292-302.
11. Gold R, Arnold DL, Bar-Or A, et al. Long-term effects of delayed-release dimethy fumarate in multiple sclerosis: interim analysis of ENDORSE, a randomized extension study. Mult Scler 2017;23:253-265.

12. Maecker HT, McCoy JP, Nussenblatt R. Standardizing immunophenotyping for the Human Immunology Project. Nat Rev Immunol 2012;12:191-200.

13. Caraux A, Klein B, Paiva B, et al. Circulating human B and plasma cells: age-associated changes in counts and detailed characterization of circulating normal CD138- and CD138+ plasma cells. Haematologica 2010;95:1016-1020.

14. Blair PA, Noreña LY, Flores-Borja F, et al. CD19(+)CD24(hi)CD38(hi) B cells exhibit regulatory capacity in healthy individuals but are functionally impaired in systemic lupus erythematosus patients. Immunity 2010;32:129-140.

15. Wu Q, Wang Q, Mao G, Dowling CA, Lundy SK, Mao-Draayer Y. Dimethyl fumarate selectively reduces memory $\mathrm{T}$ cells and shifts the balance between Th1/Th17 and Th2 in multiple sclerosis patients. J Immunol 2017;198:3069-3080.

16. Zecca C, Antozzi CG, Torri Clerici V, et al. Severe multiple sclerosis reactivation during prolonged lymphopenia after dimethyl fumarate discontinuation. Acta Neurol Scand 2018;137:623-625

17. Khatri BO, Garland J, Berger J, et al. The effect of dimethyl fumarate (Tecfidera) on lymphocyte counts: a potential contributor to progressive multifocal leukoencephalopathy risk. Mult Scler Relat Disord 2015;4:377-379.

18. Gheuens $\mathrm{S}$, Bord E, Kesari S, et al. Role of $\mathrm{CD} 4^{+}$and $\mathrm{CD} 8^{+} \mathrm{T}$-cell responses against JC virus in the outcome of patients with progressive multifocal leukoencephalopathy (PML) and PML with immune reconstitution inflammatory syndrome. J Virol 2011; 85:7256-7263.

19. Li R, Rezk A, Ghadiri M, et al. Dimethyl fumarate treatment mediates an antiinflammatory shift in B cell subsets of patients with multiple sclerosis. J Immunol 2017;198:691-698.

20. Karnell FG, Lin D, Motley S, et al. Reconstitution of immune cell populations in multiple sclerosis patients after autologous stem cell transplantation. Clin Exp Immunol 2017;189:268-278.

21. Espinosa E, Romero-Rodriguez DP, Cantoral-Diaz MT, Reyes-Teran G. Transien expansion of activated CD8(+) T cells characterizes tuberculosis-associated immune reconstitution inflammatory syndrome in patients with HIV: a case control study. J Inflamm 2013;10:21

22. Nakanjako D, Ssewanyana I, Mayanja-Kizza H, et al. High T-cell immune activation and immune exhaustion among individuals with suboptimal CD4 recovery after 4 years of antiretroviral therapy in an African cohort. BMC Infect Dis 2011 ; $11: 43$.

23. Antonelli LR, Mahnke Y, Hodge JN, et al. Elevated frequencies of highly activated CD4+ $\mathrm{T}$ cells in HIV+ patients developing immune reconstitution inflammatory syndrome. Blood 2010;116:3818-3827.

24. Khatri BO, Tarima SS, Essig B, Sesing J, Olapo T. Delayed lymphocyte re-population following discontinuation of dimethyl fumarate and after switching to other disease modifying drug therapies. Mult Scler Relat Disord 2017;18:60-64.

25. Hoglund RA, Polak J, Vartdal F, Holmoy T, Lossius A. B-cell composition in the blood and cerebrospinal fluid of multiple sclerosis patients treated with dimethyl fumarate. Mult Scler Relat Disord 2018;26:90-95.

26. Spencer CM, Crabtree-Hartman EC, Lehmann-Horn K, Cree BA, Zamvil SS. Reduction of CD8(+) T lymphocytes in multiple sclerosis patients treated with dimethyl fumarate. Neurol Neuroimmunol Neuroinflamm 2015:2:e76. 


\section{Neurology}

\section{Effect of dimethyl fumarate on lymphocytes in RRMS: Implications for clinical practice \\ Devangi Mehta, Catherine Miller, Douglas L. Arnold, et al.}

Neurology 2019;92;e1724-e1738 Published Online before print March 27, 2019

DOI 10.1212/WNL.0000000000007262

\section{This information is current as of March 27, 2019}

\section{Updated Information \&} Services

References

Citations

Subspecialty Collections

Permissions \& Licensing

Reprints including high resolution figures, can be found at: http://n.neurology.org/content/92/15/e1724.full

This article cites 25 articles, 6 of which you can access for free at: http://n.neurology.org/content/92/15/e1724.full\#ref-list-1

This article has been cited by 3 HighWire-hosted articles: http://n.neurology.org/content/92/15/e1724.full\#\#otherarticles

This article, along with others on similar topics, appears in the following collection(s):

\section{All Clinical trials}

http://n.neurology.org/cgi/collection/all_clinical_trials

Multiple sclerosis

http://n.neurology.org/cgi/collection/multiple_sclerosis

Information about reproducing this article in parts (figures,tables) or in its entirety can be found online at:

http://www.neurology.org/about/about_the_journal\#permissions

Information about ordering reprints can be found online:

http://n.neurology.org/subscribers/advertise

Neurology ${ }^{\circledR}$ is the official journal of the American Academy of Neurology. Published continuously since 1951, it is now a weekly with 48 issues per year. Copyright Copyright ( 2019 The Author(s). Published by Wolters Kluwer Health, Inc. on behalf of the American Academy of Neurology.. All rights reserved. Print ISSN: 0028-3878. Online ISSN: 1526-632X.

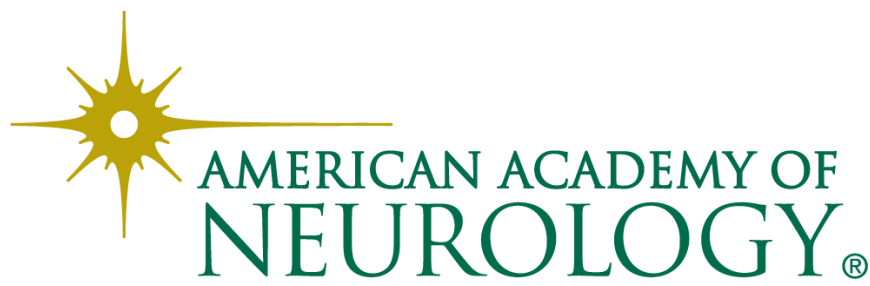

